\title{
The Spanish Petroleum Systems and the Overlooked Areas and Targets
}

\author{
W. Martínez del Olmo \\ Oil and Gas Capital. s.l. Ángel Muñoz ,3, 28043 Madrid \\ wmartinez@oilandgascapital.com
}

\begin{abstract}
The structural complexity of the Spanish territory hampered the development of large sedimentary basins with a time-space evolution that could have allowed the accumulation and preservation of large hydrocarbon deposits. In spite of this, including the few exploratory wells drilled (3.13 wells / 1,000 square miles), Spain (including on and offshore) has up to eight geological systems with present or past commercial hydrocarbon fields: the Gulf of Cadiz-Guadalquivir Miocene foreland basin, the Cretaceous of the Betic ranges, the Jurassic and Lower Miocene of the Western Mediterranean Sea, the Albian sands of the Rioja Paleogene foreland basin, the Platform-Basin of the onshore Cantabrian basin, the Ypresian of the Pyrenees thrust belts, and the westward continuity of the Aquitania foreland basin in the Gulf of Biscay. There are other remaining areas that supposedly contain an exploratory potential that could be much higher than the systems mentioned above: the deep waters of the Mediterranean and Cantabrian seas and the Atlantic Ocean of the Canary Islands, the Mesozoic covered by the olistostromes of the Betic ranges, the onshore Triassic sandy reservoirs and the onshore Carboniferous sub-basins found throughout the mainland. These areas have an even lower level of exploration (0.26 wells / 1,000 square miles).
\end{abstract}

Keywords: geology, geochemistry, hydrocarbons, overlooked areas, petroleum systems.

\section{Los sistemas productivos de gas y petróleo de España y áreas y objetivos exploratorios pendientes}

\begin{abstract}
RESUMEN
La complejidad geológica del área España no ha propiciado el desarrollo de grandes cuencas sedimentarias que permitiesen la acumulación y preservación de grandes yacimientos de petróleo y gas. A pesar de ello y del reducido número de sondeos exploratorios (1,2 sondeos / $1.000 \mathrm{~km}^{2}$ ) España contiene ocho sistemas geológicos que han producido hidrocarburos: Golfo de Cádiz-Guadalquivir, Prebético, Golfo de Valencia (2), Rioja, Pirineos, Plataforma-Cuenca Norcastellana, y Mar Cantábrico. A la vez, existen otros, en los que a pesar de su aún más bajo nivel de exploración $\left(0,1\right.$ sondeo $\left./ 1.000 \mathrm{~km}^{2}\right)$ conocemos que albergan un potencial exploratorio cuya magnitud, por falta de datos de sísmica y sondeo, desconocemos. El análisis de los sistemas productores de hidrocarburos revela que, por la complejidad y pequeñas dimensiones de nuestras cuencas sedimentarias, estos son muy diversos en lo que se entiende como condiciones necesarias para los cuatro componentes (roca madre, almacén, trampa, sello) y tres procesos (maduración-tiempo de expulsión del hidrocarburo, distancia de migración y condiciones de preservación). Desde otro punto de vista, existen datos suficientes para estimar aquellos probables sistemas geológicos que constituyen asignaturas exploratorias pendientes, tales como: aguas profundas del Mediterráneo, Cantábrico e Islas Canarias, cuencas del Carbonífero, Triásico pre-salino y Mesozoico bajo los olistostromas de la cordillera Bética. De otra parte, también conocemos el potencial teórico, que dos bien caracterizadas rocas madre de la cuenca cantábrica (Lías y Albiense-Cenomaniense) albergan, si en España, se realizase la técnica de la fracturación hidráulica, técnica y posibilidades que no abordamos por falta de experiencia personal.
\end{abstract}

Palabras clave: Exploración, Geología, Geoquímica, Sistemas petrolíferos, Sondeos. 
W. Martínez del Olmo, 2019. The Spanish Petroleum Systems and the Overlooked Areas... Boletín Geológico y Minero, 130 (2): $289-315$

\author{
VERSIÓN ABREVIADA EN CASTELLANO
}

\title{
Introducción
}

La España marina y terrestre, susceptible de exploración de hidrocarburos se extiende sobre más de 2 millones de $\mathrm{km}^{2}$, gran superficie tan solo investigada por 560 sondeos exploratorios, concentrándose el $75 \%$ de ellos en cinco cuencas: Cantábrica, Mediterráneo, Guadalquivir-Golfo de Cádiz, Pirineos y Valle del Ebro (Figs. 1 y 2).

La historia exploratoria puede diferenciarse en cuatro etapas que partieron de tecnologías, medios y bases de datos muy diferentes (Fig. 3): 1) 1944-1955 con el único uso de una deficiente Geología de superficie. 2) 1955-1968 sin el soporte de la moderna Geoquímica del Petróleo. 3) 1968-2010 con una alta concentración de sondeos en dos cuencas productivas (Golfo de Valencia y Guadalquivir-Golfo de Cádiz). 4) 2010-2017 perforación de un único sondeo exploratorio, inexplicable y cierto en un país que posee cuencas geológicas productivas e importa el 99,8\% de sus necesidades.

Histórico que además ha sido condicionado por cuatro circunstancias, ajenas al potencial de las cuencas españolas: 1) La insistente exploración en aquellas cuencas, que desde muy temprano mostraron indicios o descubrimientos comerciales (Pirineos en Benabarre, Serrablo, y Centenera; Cantábrica en Ayoluengo, Hontomin y Tozo; Golfo de Valencia en Amposta, Dorada, Casablanca y Guadalquivir-Golfo de Cádiz en Casas Nieves, Palancares y Poseidón. 2) La complejidad estructural y la calidad de la vieja sísmica, en general y especialmente, (Fig.4) por el alto relieve de las cadenas montañosas alpinas (Cantábrica, Pirineos, Ibérica, Bética) que propician un intenso lavado-flujo de agua meteórica. 3) La insuficiente subsidencia cenozoica de las cuencas de ante-país (Duero, Ebro, Tajo) que condicionó la ausencia de maduración de las rocas madres del Mesozoico-Cenozoico, motivo por el que la falta de indicios y la baja calidad de la vieja sísmica, dejó sin explorar el Paleozoico subyacente. 4) Los bajos precios del petróleo y del gas, y los altos precios de los servicios de sísmica y sondeo. 5) La desacertada e injusta interpretación de que el objetivo real de muchos Permisos de Investigación solicitados es la denostada fracturación hidráulica.

A pesar del reducido número de sondeos exploratorios (Figs. 2 y 3) la actividad condujo al descubrimiento de 67 yacimientos de gas y petróleo (39 desarrollados comercialmente y 24 no desarrollados).

Las diversas causas de este "aparente" fracaso exploratorio las fijamos en: 1) La realización de ensayos de producción (DST) en pozo abierto. 2) La escasa calidad y malla poco densa de la sísmica utilizada, especialmente cuando es terrestre. 3) El lavado hidrodinámico de los gruesos paquetes carbonatados o arenosos que algunas cuencas, con altos relieves próximos a los objetivos exploratorios propician. 4) La antigüedad de la actividad exploratoria.

Sin embargo, en las siete cuencas que contienen ocho sistemas donde la generación-migración fue eficiente (Fig. 5) aún y a pesar de que el mayor número de sondeos se hizo antes de 1990 y sin el concurso de sísmica 3D, los éxitos geológico y comercial pueden cifrarse en el 12 y el $7 \%$. Porcentajes que no difieren mucho de otros países mucho más explorados.

Los ocho sistemas petrolíferos (Mioceno del Guadalquivir-Golfo de Cádiz, Golfo de Valencia Jurásico, Golfo de Valencia Mioceno, Plataforma interna-talud del Prebético, foreland de la Rioja, cuenca Cantábrica marina y terrestre, Pirineos y la Aquitania del Golfo de Vizcaya, son tan diferentes, en lo que concierne a la edad de la roca madre, el tiempo de migración, las vías de la misma (vertical, horizontal o mixta), la distancia alcanzada por la migración, el almacén, el sello, el tipo de trampa y la conservación de una acumulación de hidrocarburos, que por su diversidad, son descritos en las figuras 6 a 15 del texto en idioma inglés.

\section{Objetivos y áreas minusvaloradas}

Si nos ceñimos a las posibilidades tipo hidrocarburos convencionales, se puede decir que derivados del bajo nivel de exploración de muchas áreas, de la calidad de las viejas líneas sísmicas y de otros condicionantes, tales como la pasada depreciación de los hidrocarburos y las campañas mediáticas contra los combustibles fósiles, el área España contiene regiones, subcuencas y niveles estratigráficos que no han sido suficientemente explorados y que conforman asignaturas pendientes (Figs. 16 a 22) que pueden ser fijadas en: 1) Áreas con generación probada en aguas poco profundas del Golfo de Valencia. 2) Aguas profundas de los mares Cantábrico, Mediterráneo, Golfo de Cádiz e Islas Canarias. 3) Cuencas del Carbonífero. 4) Almacenes arenosos del Triásico. 5) Autóctonos y parautóctonos bajo el Olistostroma Subbético de la Cordillera Bética. 6) Trampas estratigráficas en las turbiditas arenosas del Cretácico Superior y en las facies canalizadas del Jurásico Superior-Cretácico Inferior (Pürbeck y Weald) de la cuenca Cantábrica.

Es evidente que todas estas posibilidades requieren un nuevo esfuerzo exploratorio con resultados no asegurados, pero también lo es, que ellas, por el hecho de estar inexploradas en áreas con generación probada, pueden alcanzar mejores perspectivas que la exploración histórica. 
W. Martínez del Olmo, 2019. The Spanish Petroleum Systems and the Overlooked Areas... Boletín Geológico y Minero, 130 (2): $289-315$

\section{Discusión}

La historia geológica de la Península lbérica es compleja y por diversas causas ella no ha propiciado cuencas sedimentarias, con superficies y espesores, capaces de generar provincias petrolíferas semejantes a las que salpican otras muchas geografías del Planeta. Ello ha motivado que desde muy temprano (1980) el área España tuviese un precario nivel de exploración, que coadyuvó a un creciente desconocimiento de sus posibilidades.

Treinta y siete años después, se debe llegar a la conclusión de que España no puede considerase lo que coloquialmente se llama un país petrolero, pero al mismo tiempo, es obvio, que aún y a pesar de su bajo nivel de exploración, en todas las cuencas sedimentarias donde ha habido generación-expulsión de petróleo y gas, se han encontrado yacimientos comerciales.

Desde los conocimientos actuales, se ha tratado de sintetizar los llamados petroleum systems: roca madre madura-migración, almacén, sello, trampa, de las cuencas productivas y se esboza la localización y modelos tectono-estratigráficos que constituyen asignaturas exploratorias pendientes, que en un país que importa el 99,8 \% del hidrocarburo que consume, sin duda, merecen un nuevo esfuerzo exploratorio.

Por la ausencia de datos geoquímicos precisos se han dejado algunos interrogantes referidos a las rocas madres que son responsables de descubrimientos no comerciales: yacimiento de Centenera, asignado, sin datos fiables, al Cretácico Inferior, Triásico de los sondeos Navajo-1 y El Coto-1, del que se mantiene la duda de si procede del Carbonífero por migración lateral o desde un Paleozoico más antiguo (Devónico, Silúrico) por migración vertical. También se ha abierto la posibilidad de una roca madre jurásica en el Prebético, y finalmente, se adelantan las posibilidades reales de nuestras inexploradas cuencas del Carbonífero, especialmente en aquellas áreas donde son evidentemente visibles en numerosas líneas sísmicas y pueden correlacionarse con cuencas productivas tipo hullas grasas.

\section{Conclusiones}

El Territorio español no puede considerarse poseedor de cuencas sedimentarias capaces de generar grandes provincias petrolíferas semejantes a las de nuestros vecinos entornos de Europa y del Norte de África. El principal motivo no es otro que el intenso plegamiento alpino y la consecuente emersión prematura de muchas áreas, y de otra parte, por el escaso desarrollo sedimentario de sus adosadas cuencas de ante-país: Duero, Ebro, Tajo, Guadalquivir-Cádiz, entre otras y de mayor volumen.

La exploración de todas estas cuencas ha sido muy deficitaria, tanto en número de sondeos por $\mathrm{km}^{2}$ de superficie prospectiva, como en el uso de modernas campañas sísmicas, que ya sea desde 2D o 3D y una moderna metodología (software) de interpretación que permitan una aceptable valoración de sus posibilidades exploratorias.

Las líneas precedentes permiten concluir que el área España:

- Posee ocho sistemas petrolíferos promovidos por rocas madre del Carbonífero (Gaviota / gas húmedo), Jurásico Inferior (Ayoluengo / petróleo y gas), Jurásico Superior (Amposta / petróleo pesado), Cretácico Inferior (Río Segura / gas húmedo), Cretácico Superior (Castillo / gas), Paleógeno (Serrablo / gas seco), Mioceno Inferior (Casablanca / petróleo ligero) y Mioceno Superior (Golfo de Cádiz-Guadalquivir / gas biogénico).

- Que otros sistemas, peor conocidos, son posibles en áreas prácticamente inexploradas: aguas profundas de Canarias, Mar Cantábrico, Mar Mediterráneo Norte, Sur y Este Balear, Meosozoico parautóctono de la Cordillera Bética, sub-cuencas del Carbonífero y niveles del Triásico pre-salino.

- Que es un país poco y mal explorado, pues prácticamente su "boom" exploratorio data de treinta años atrás.

Las anteriores líneas aglutinan circunstancias suficientes por las que debe considerarse que el área España aún alberga posibilidades reales. Muchas grandes compañías lo entendieron así, pero las dificultades operacionales, logísticas y de todo tipo, que han promovido las campañas mediáticas lanzadas contra los combustibles fósiles y la técnica de la fracturación hidráulica, han hecho que estas compañías obvien su interés por la exploración de España y hayan renunciado a decenas de Permisos de Investigación que tres-cuatro años atrás habían solicitado.

\section{Introduction}

The Spanish territory, which is subject to hydrocarbon exploration both onshore and offshore, extends over more than 2 million $\mathrm{km}^{2}$ (Álvarez de Buergo, 2005,
Martínez del Olmo, 2004c) but this large surface area has scarcely been explored. Only 560 exploratory wells have been drilled; and they are very unevenly distributed with $75 \%$ of them in five basins: the Cantabrian, Valencia Gulf, Guadalquivir-Gulf of Cadiz, 
Pyrenees and Ebro Valley basins (Figs. 1 and 2). According to the different available technologies and databases, the exploratory history includes four main stages (Fig. 3): 1) 1944-1955 with only very scarce accurate surface geology, 2) 1955-1968 without the support of modern petroleum geochemistry, 3) 19682010 with a high concentration of exploratory wells in two productive basins (Gulf of Valencia and Guadalquivir-Cadiz), and 4) 2010 - up to now with only one exploratory and one appraisal well (Viura-12 ) in the Rioja basin.

This poor exploratory effort has been conditioned by three circumstances (Martínez del Olmo and Motis, 2012) unrelated to the hydrocarbon potential of the Spanish basins: 1) the industry did keep exploring those basins with very early signs of hydrocarbon shows or commercial discoveries, in particular: Benabarre, Centenera, Serrablo in the Pyrenees; Ayoluengo, Hontomin, Castillo in the Cantabrian basin; Amposta, Dorada, Casablanca in the Gulf of Valencia; and Casas Nieves, Palancares, Gulf of Cádiz B-1, Gulf of Cádiz D-1, Atlántida 2-1, etc., in the Guadalquivir-Gulf of Cadiz. 2)The old seismic surveys show poor quality in most cases. 3) And finally, the modern low oil and gas prices and the high price drilling-seismic service create economic problems for many exploration projects. In addition to these external factors, the structural complexity, small volume and steep orography of the Spanish alpine mountain ranges (Cantabrian, Pyrenees, Iberic, and Betic, see Fig. 4) boost intense fresh water flushing in numerous structural traps close to the reservoir outcrop. The forelands (Duero, Ebro, Tajo) are generally not mature due to the low Cenozoic subsidence. Finally, the Miocene extensional basins (Alboran Sea) show a problematic lack of clean sandy reservoirs.

Despite these facts, 560 real exploratory wells were drilled, 63 oil and gas fields were discovered, with 39 of them being developed and 24 remaining undeveloped. The causes of this "apparent" failure are: 1) the drill stem test (DST) done in open-hole conditions which is a first relative and imprecise evaluation of a commercial hydrocarbon reservoir. 2) The poor quality and low dense grid of the onshore seismic surveys. 3) The hydrodynamic fresh water flushing of thick carbonate or sandy packages in basins with high topography.

However, in the seven sub-basins where the generation-migration was efficient, the geological success is $11.25 \%$ and the commercial success rate $6.9 \%$ (Fig. 5). The age of the drilling (most of the wells before 1990) and the lack of 3D seismic data must be taken into account.

A synthesis of source rocks, reservoirs, hydrocar- bon fields and migration way types of these seven sub-basins with developed and non-developed hydrocarbon fields is represented in Figure 6. In the following pages, the possibilities of these oil systems according to the success rates shown will be summarized.

\section{Guadalquivir-Cadiz Miocene Foreland Basin}

The first indication of gas generation in the Guadalquivir Basin was found in the Casas Nieves-1 well (1967) where a test drill stem test (DST) in an open hole produced gas and salt water. After that, a lot of technical papers considered that the basin had generated gas but it did not contain reservoir facies. This mistake, due to the lack of definition of the old seismic lines, blocked exploratory activity for 10 years. In 1973 the Gulf of Cádiz B-1 showed a gas accumulation in a carbonate high, and in 1978 the Gulf of Cádiz B-3 achieved a production of $9 \times 10^{6} \mathrm{ft}^{3} / \mathrm{d}$ in a Late Miocene sandy turbidite only $1 \mathrm{~m}$ thick.

That opened up the exploration of the Guadalquivir-Cadiz Basin (Figs. 2, 3, 5, 6, 7 and 8) which led to the discovery of 29 commercial gas fields ( 3 offshore and 26 onshore) with an exploration success ratio above $71 \%$ and 115 billion cubic feet (BCF) accumulated production.

The high success ratio is related to the improvement in the seismic quality and especially to the development of two new processing techniques: firstly the bright spot in preserved amplitude (PAM) and then the amplitude versus offset (AVO).

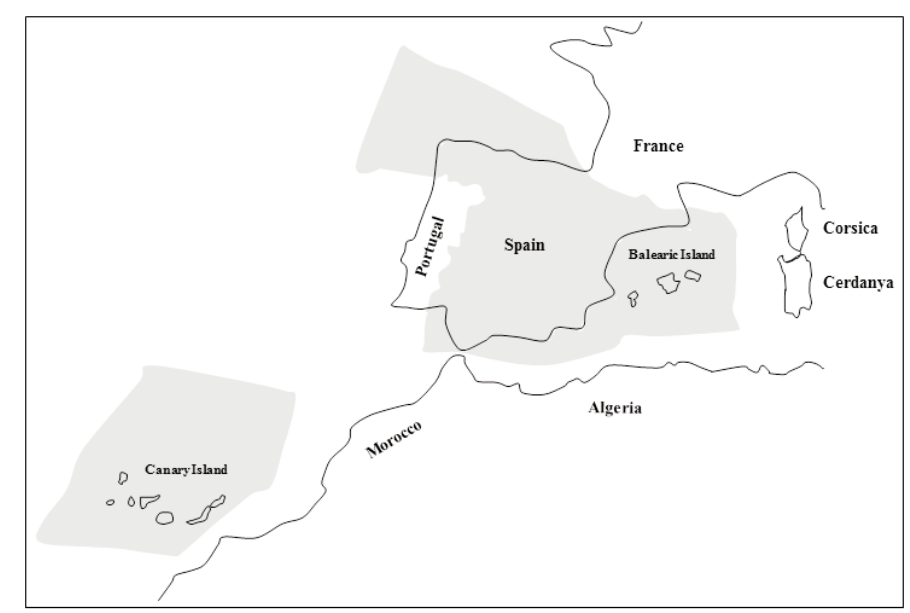

Figure 1. Spanish jurisdictional areas (>2.0 million square kilometers).

Figura 1. Áreas jurisdiccionales españolas (> 2,0 millones de $\mathrm{km}^{2}$ ). 


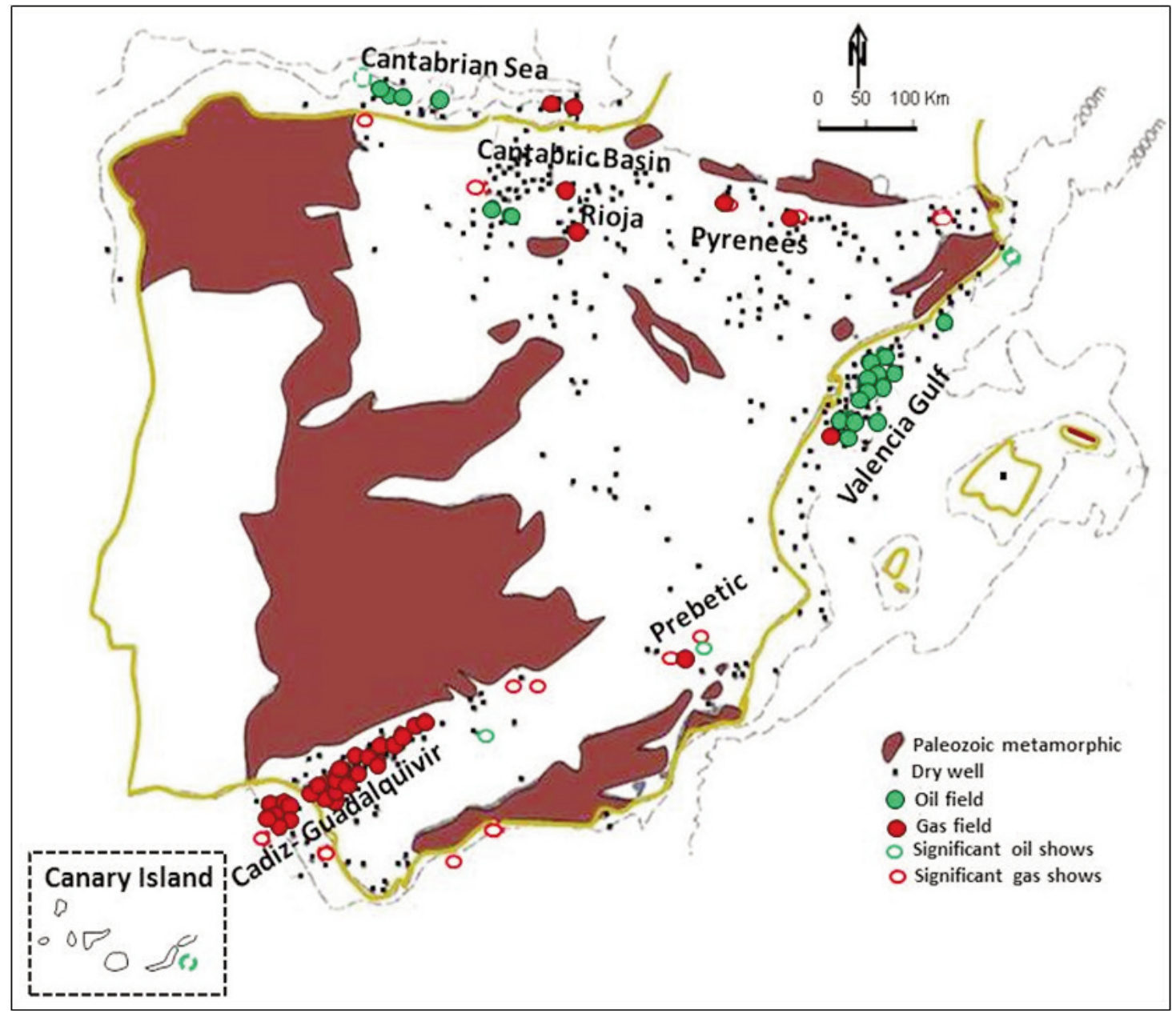

Figure 2. Exploratory wells (1944 to 2017) and their results (from Oil and Gas Capital data base).

Figura 2. Sondeos exploratorios (1944 a 2017) y sus resultados (archivos de Oil and Gas Capital).

The data available in this gas system (Martínez del Olmo et al., 1984., Suárez Alba et al., 1989; Riaza and Martínez del Olmo, 1996; Martínez del Olmo et al., 1998, 2005; Ledesma, 2000; Martínez del Olmo and García Mojonero, 2000; García Mojonero and Martínez del Olmo, 2001; García Mojonero et al., 2001; Martínez del Olmo et al., 2005; Martínez del Olmo and Martin, 2016a, 2016b) indicate that:

- High porosity and permeability reservoirs can be found in the onshore Guadalquivir and offshore Cadiz Gulf sandy turbiditic formations (Late TortonianMessinian). The first one (Guadalquivir Sands Formation) is interpreted as a channel-channel leveelobe system in a high-stand system tract (HST) promoted by deltaic hiperpicnic flows that introduce a multi-bed of sandy reservoirs with NE-SW and NWSE flow directions. The second one (the Guadiana sands formation) is a low-stand system tract (LST) encouraged by the Messinian sea level fall and has a sedimentary model with the thick and continuous basin floor fan (BFF), the channel-levee facies in the slope fan complex (SFC) and the very thin sandy levels of the prograding complex (PC).

- Traps are generally stratigraphic on channellevee-lobe facies and due to small relieves created by the shale-sand differential compaction.

- The gas generation type is biogenic from marine clays located a few metres under the turbidite reservoirs. Many analyses obtained from outcrop and well samples show values of total organic carbon (TOC) ranging $0.3-0.7 \%$ in sometimes thick source rocks (200-400 m).

- The migration is supposed to be very early and with a vertical-lateral short pathway.

-The small size of the gas fields ( 2 to $50 \mathrm{BCF}$ ) could be due to the small trap volumes, the amount of gas generated and/or the early migration inefficiency.

Possibly, $500 \mathrm{~km}$ seismic onshore new acquisi- 


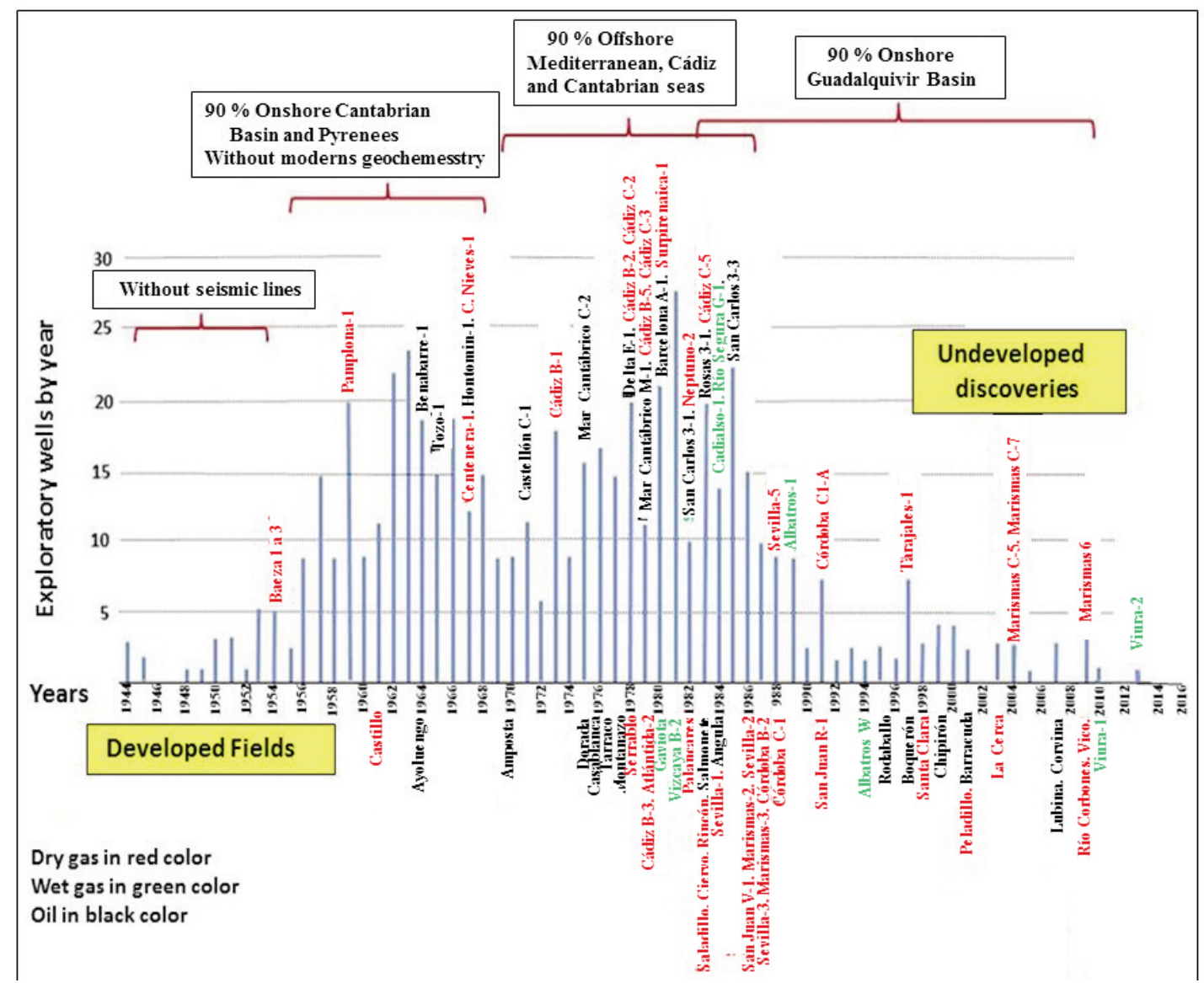

Figure 3. Exploration history comprehending 560 exploratory wells (actualized from Martínez del Olmo and Motis, 2012). Figura 3. Histórico exploratorio (actualizado de Martínez del Olmo y Motis, 2012).

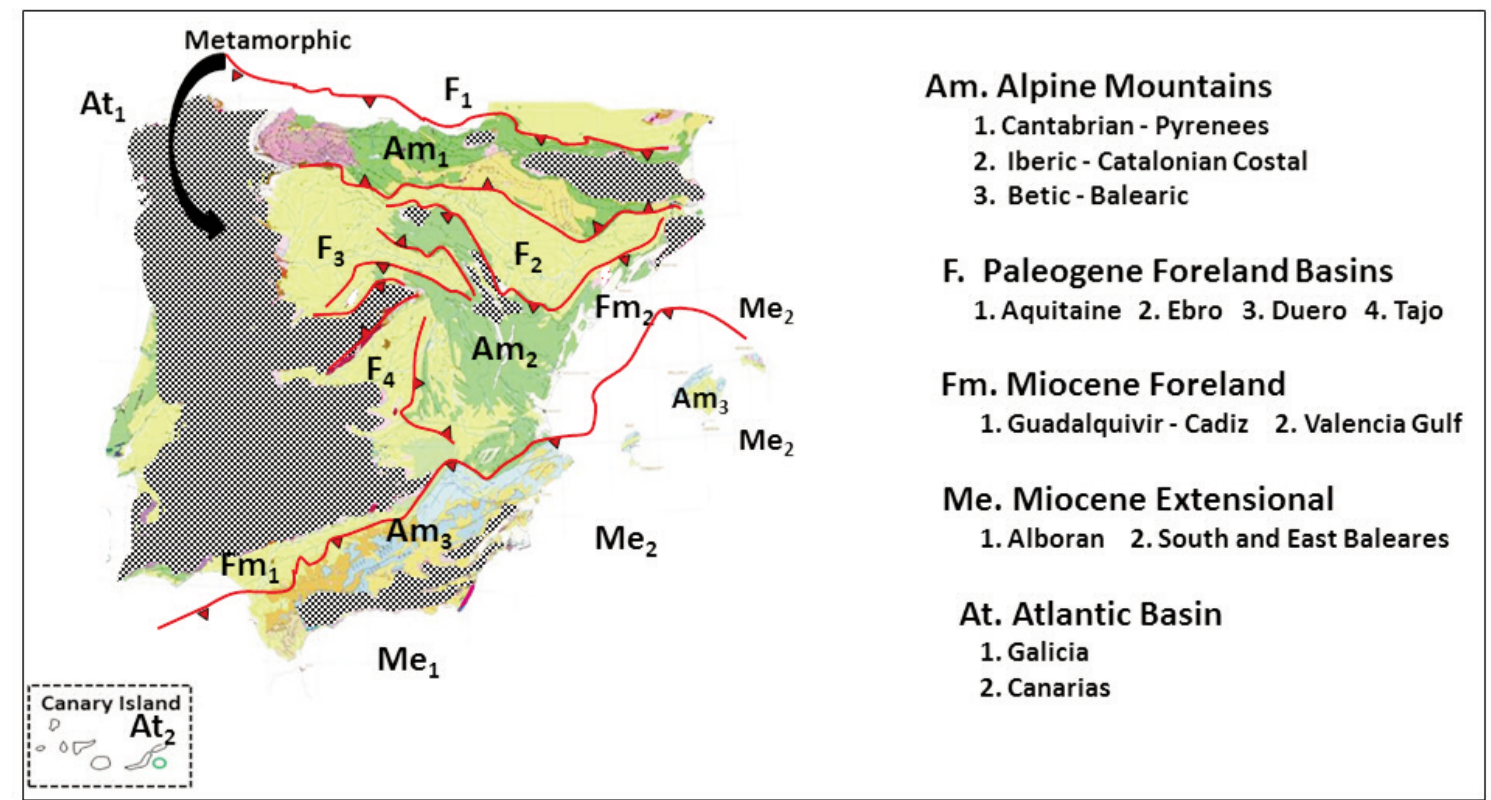

Figure 4. Regional geology: basin types with hydrocarbon possibilities.

Figura 4. El tipo de las cuencas susceptibles de exploración para hidrocarburos. 


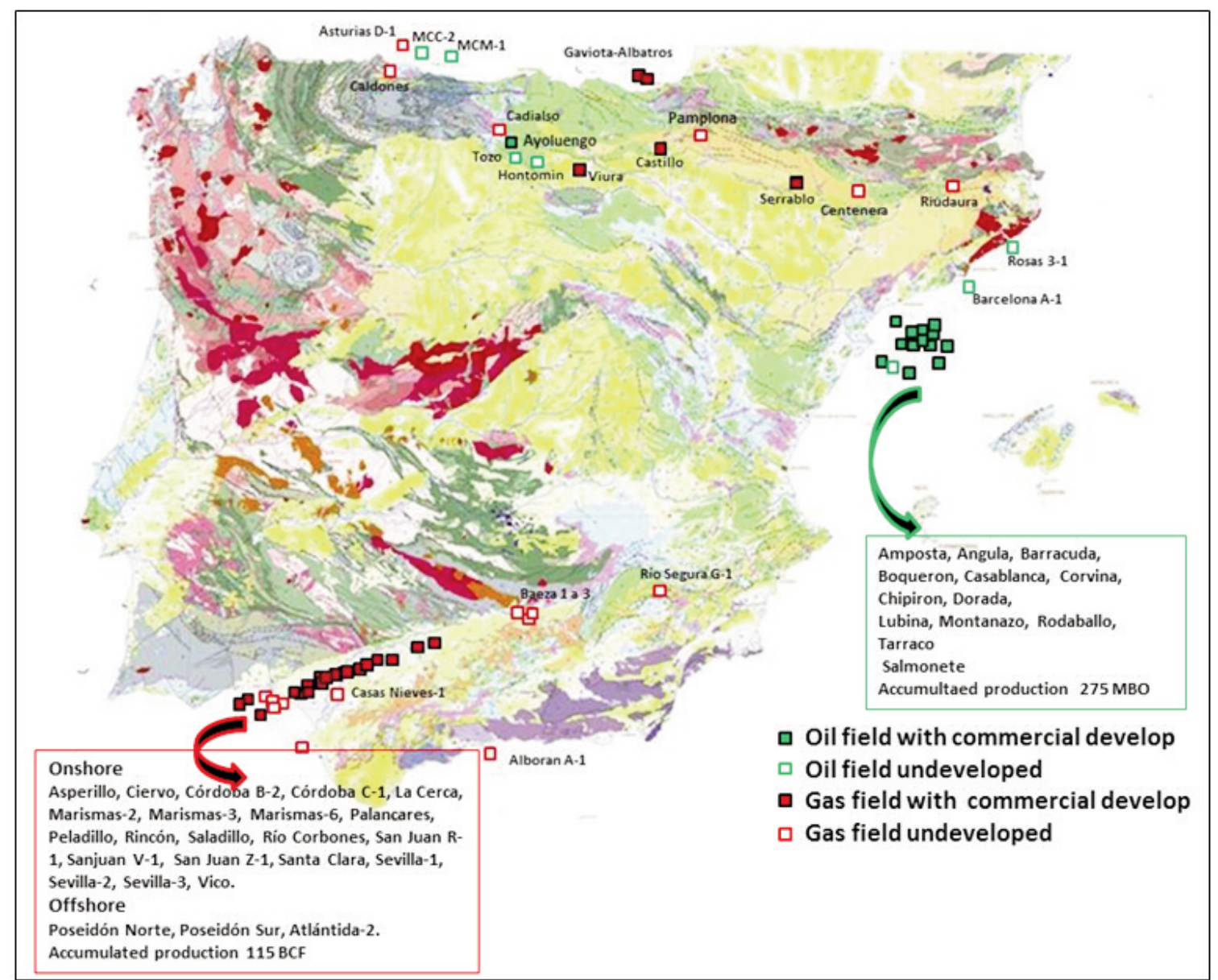

Figure 5. Developed and undeveloped oil and gas discovery locations.

Figura 5. Yacimientos de petróleo y gas: explotados y no explotados comercialmente.

tions could easily bring about the discovery of 20 to 30 new gas fields. However this assumption cannot be applied to the Gulf of Cadiz, where the seismic grid and their original quality have left only a few undrilled prospects.

\section{Gulf of Valencia (Western Mediterranean Sea)}

The existence of an oil province beyond the eastern Spanish Coast was confirmed in two phases: 1) The first phase began in 1970 with the discovery of the Amposta oil field of the Amposta marine $\mathrm{C}-1$ and $\mathrm{C}-2$ wells, and the identification of the KimmeridgianPortlandian source rock (Ascla Formation) in both wells and in the Vinaroz-1, located ten kilometres west of the oil field. 2) The second phase began in 1975 (Fig. 3) with the discovery of the Casablanca and Dorada oil fields. The very different quality $\left(\mathrm{API}^{\circ}\right)$ and biomarkers found in both fields compared to the
Amposta oil allowed the identification of a second source rock, the Burdigalian-Langhian Casablanca Formation. The absence of this source in the Dorada oil field led to different interpretations concerning: a) the pathway migration distance and the migration model, b) the same or different migration timing from the two different source rocks, and c) the continuity and degree of maturity of both source rocks in a wide region $\left(120,000 \mathrm{~km}^{2}\right)$ that in 1975 was highly unexplored.

Despite the lack of regional accurate data, the four latest discoveries triggered an exploratory activity that enclosed the acquisition of thousands of kilometres of seismic lines and sixty new exploratory wells during the following 10 years (1975-1985). This activity led to new commercial (Montanazo C, Tarraco, Salmonete, Angula and Rodaballo) and non-commercial (Delta E-1, Barcelona A-1, San Carlos 3-1, Tarragona D-1 and Rosas 3-3) discoveries (Fig. 3). Nevertheless, the total amount of these newly discov- 
W. Martínez del Olmo, 2019. The Spanish Petroleum Systems and the Overlooked Areas... Boletín Geológico y Minero, 130 (2): $289-315$

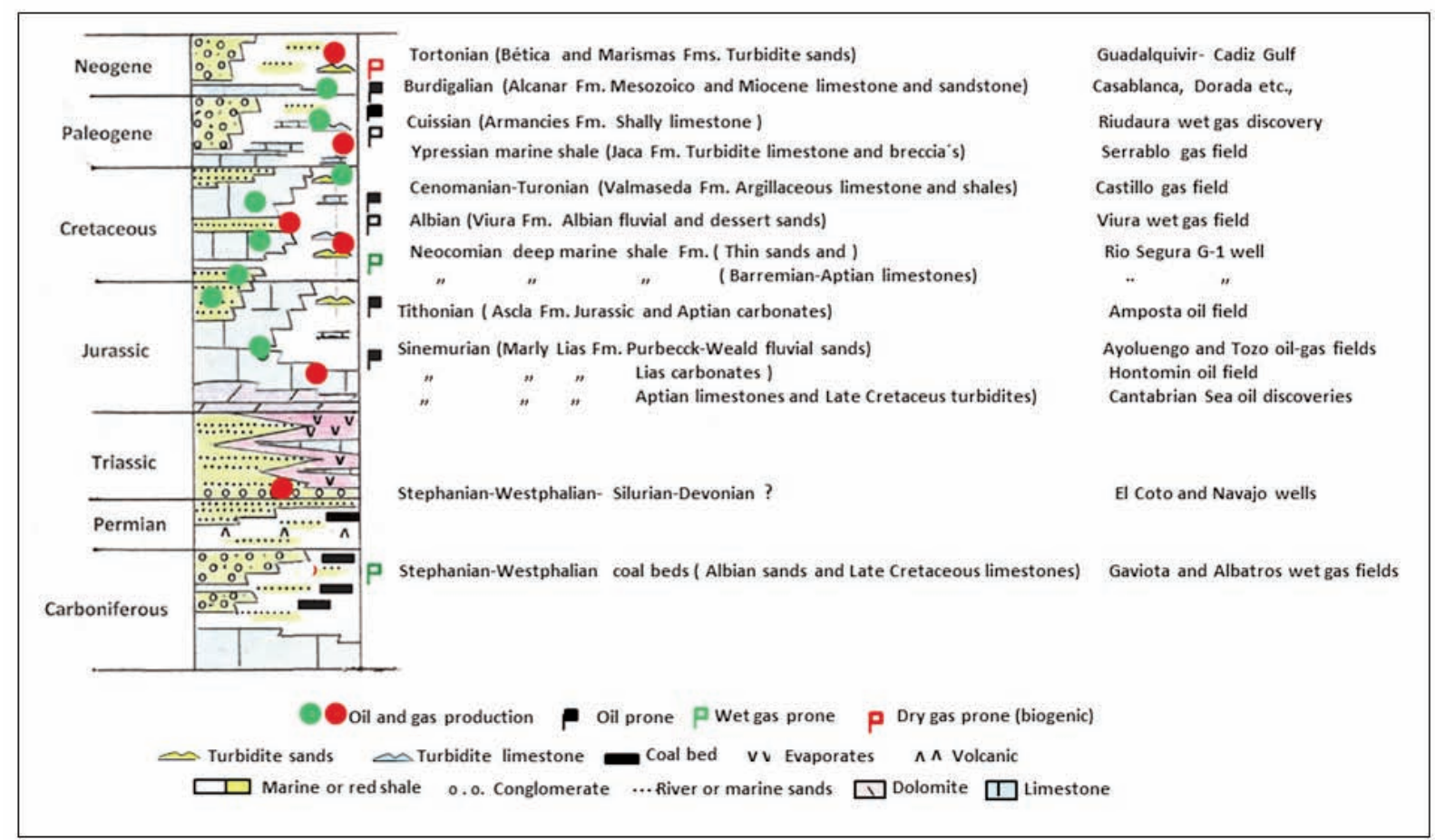

Figure 6. A) Source rocks, reservoirs and correlate oil and gas fields in Spain. B) Migration pathway and hydrocarbon systems (from Martinez del Olmo and Motis, 2012).

Figura 6. A) Correlación rocas madres-yacimientos de petróleo y gas. B) Vías de migración y sistemas petrolíferos (según Martínez del Olmo y Motis 2012).

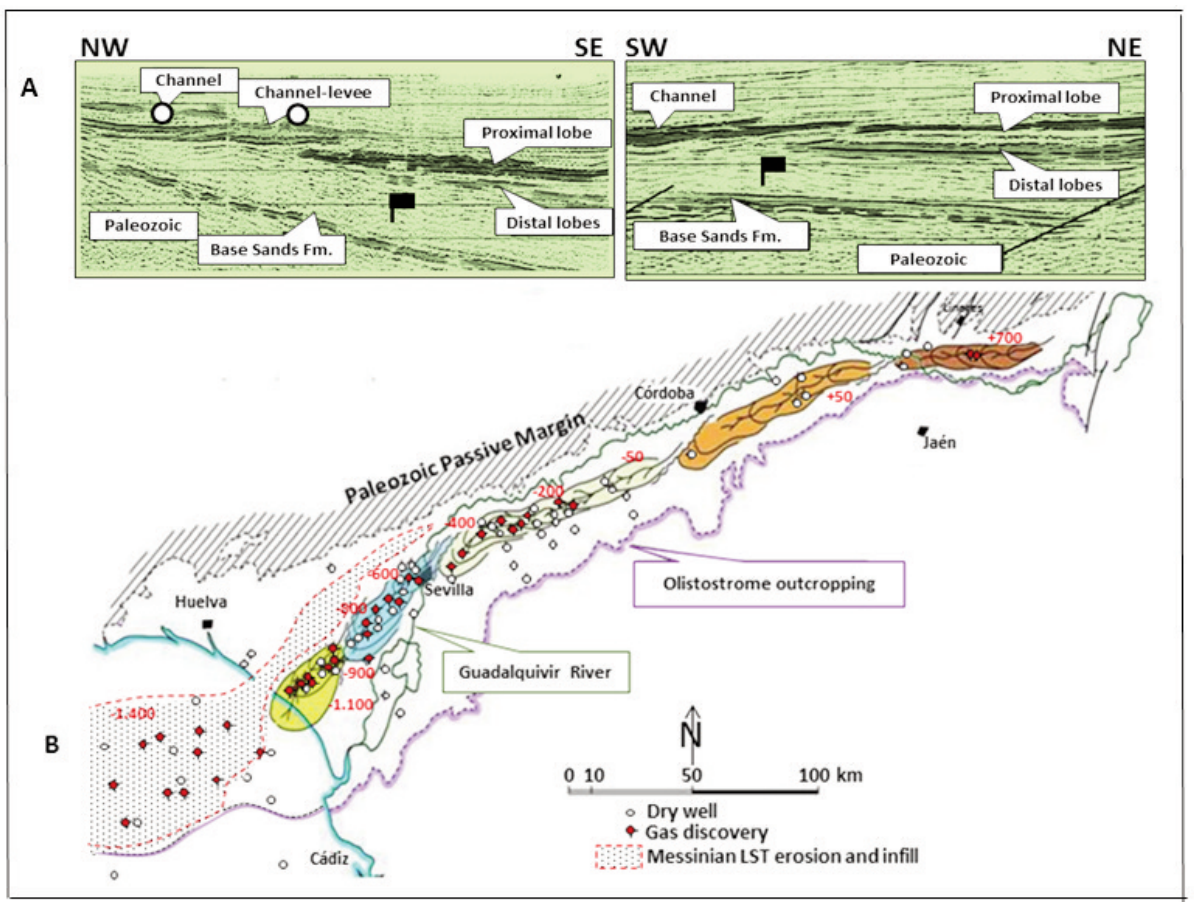

Figure 7. Guadalquivir-Cadiz Basin: A-B) Onshore Guadalquivir Sands Formation turbidite system examples in dip and strike seismic lines. C) Sedimentary model of the basin. Red numbers are the formation top in metres above or below sea level. (Modified from Martínez del Olmo et al., 2005).

Figura 7. Cuenca Guadalquivir-Cádiz: A-B) La Fm. Arenas del Guadalquivir en líneas sísmicas paralela y perpendicular al flujo turbiditico. C) Modelo sedimentario de la Fm, Arenas del Guadalquivir. Cifras en rojo indican el techo, en metros y referidas al nivel del mar. (Modificado de Martínez del Olmo et al. 2005). 


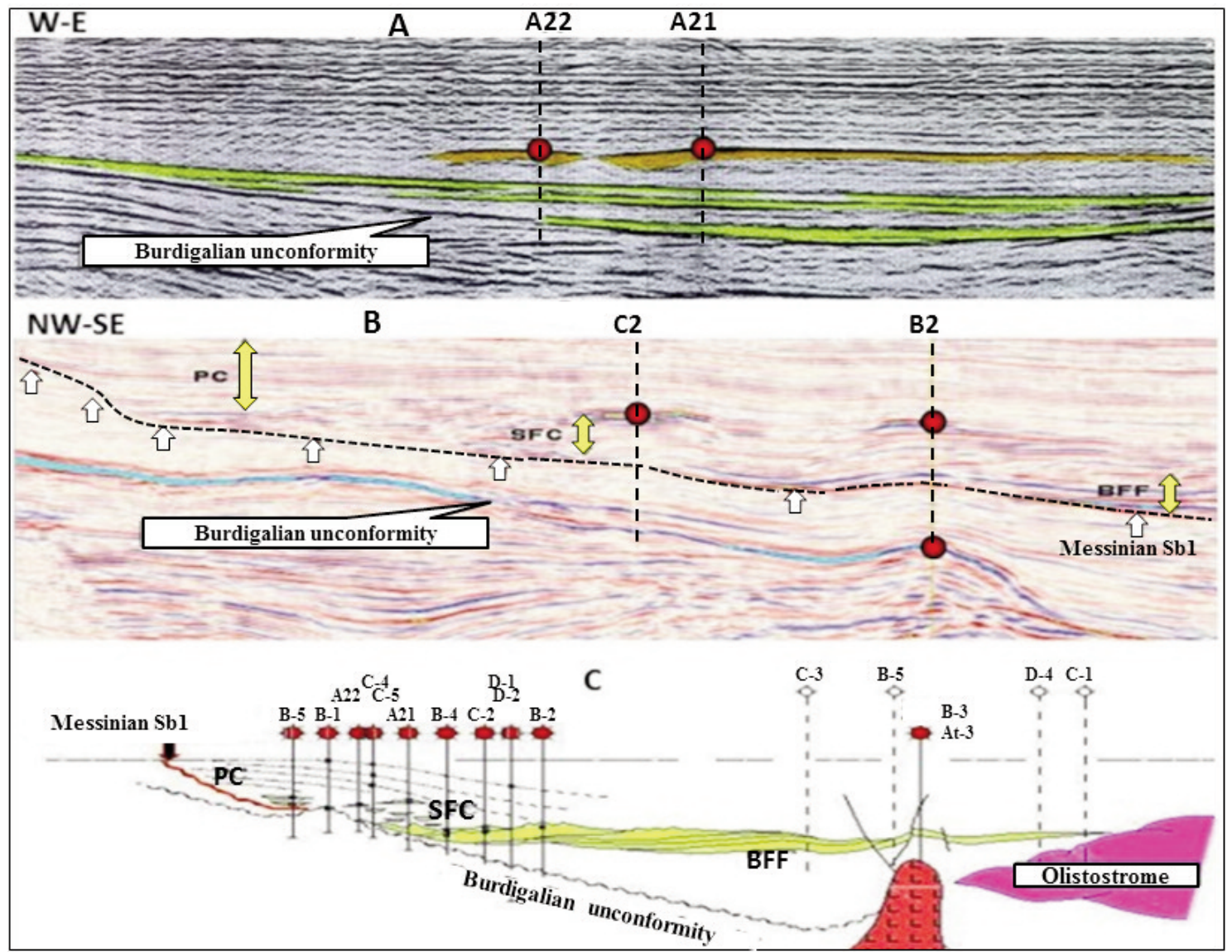

Figure 8. Guadalquivir-Cadiz Basin: A-B) Offshore Guadiana Sands Formation gas field locations (PC-prograding complex, SFC-slope fan complex, BFF-basin floor fan). The small arrows mark the intra-Messinian discontinuity sequence boundary type 1 (Sb). C) Sedimentary model and gas discoveries. (modified from Martínez del Olmo et al, 2005).

Figura 8. Cuenca Guadalquivir-Cádiz: A-B) Modelo sedimentario de la Fm. Arenas del Guadiana (PC complejo progradante, SFC complejo canalizado, BFF abanico de fondo). Flechas rojas señalan la discontinuidad intra-Messiniense tipo1 (Sb). C) Modelo sedimentario con la localización de los descubrimientos de gas. (modificado de Martínez del Olmo et al., 2005).

ered reserves was less than those previously discovered in Amposta, Casablanca and Dorada, which represented the dream curve.

Due to the disappointing situation, in the next 20 years only Casablanca satellites were drilled (Boqueron, Chipiron, Barracuda, Corvina and Lubina; Fig 5). At present, the accumulated production from the Mediterranean oil fields is $276 \times 10^{6} \mathrm{BO}$.

From a lot of data (Watson, 1982; Martínez del Olmo and Esteban, 1983; Demaison and Bourgeois, 1985; Orlopp, 1988; Stamplfi and Höcker, 1989; Seemann, et al., 1990; Álvarez de Buergo and Meléndez-Hevia, 1994; De la Cruz, 1995; Martínez del Olmo, 1996; Melendez-Hevia and Alvaréz de Buergo, 1996; Rossi, et al., 2001; Martínez del Olmo and MalloGarcía, 2002; Vallaure et al., 2003; Martínez del Olmo, 2004b; Varela, et al., 2005), this petroleum system can be characterized by:

- Two marine source rocks (Kimeridgian-Thitonian and Burdigalian-Langhian) establish two petroleum systems with different source-rock maturity models and migration modes (Fig. 9).

- Since the traps in both systems are very similar (paleo-reliefs in the Miocene-Mesozoic unconformity) and both are sealed by Miocene clays, it can be interpreted that the expulsion-migration from both systems was very close in time (Pliocene-Pleistocene).

- The Jurassic system is interpreted as short-distance vertical migration, but the Miocene petroleum system shows clear possibilities of middle-long distance horizontal migration following the MioceneMesozoic unconformity carrier bed (Dorada and Tarragona D-1 are good examples of this).

- The very high permeability of the reservoir in Amposta Marino C-2 (12,350 BOD produced), Tarragona E-1 $(14,700)$ and Casablanca-8 $(19,000)$ has been interpreted as: a) the bulk of the reservoir is due to an Oligocene-Eocene tropical karst on the 
Mesozoic carbonates that originally had matrix porosity under the $2-3 \%$, and b) the Miocene basal transgressive system that onlaps the regional unconformity is composed by breccia and carbonate conglomerates that are also part of the reservoir.

- Both the oil field types (Amposta and Casablanca) are connected to the aquifers recharged from Mesozoic carbonate outcrops nearby onshore and the costal line. That strong water drive caused problems in the final evaluation in some exploration wells that had a marine water intrusion in the open hole or DST tests done very close to the oil water contact $(\mathrm{OWC})$. The result is that many discoveries initially considered non-commercial due the oil and water production could become commercial; this could be the case for Barcelona Marino A-1, Bocarte-1, Breca-1, Necora-1, Sardina-1 and Tortuga-1.
Due to the lack of 3D seismic cubes, many exploration wells were located on supposed carbonate paleo-reliefs that finally were Mesozoic and Paleogene clays that could not be karstified and early Miocene volcanic flows badly interpreted as the Miocene-Mesozoic unconformity.

There are only 13 wells targeting the Jurassic source rock and 54 wells the Miocene system, but the commercial success rate is very similar (24\%).

\section{Prebetic Outer Platform-Slope (Betic Ranges)}

The Betic Cordillera is the result of two tecto-sedimentary main stages: 1) an Atlantic type passive margin established during a long time (Triassic-Early Miocene) on the southern edge of the Iberian Shield.

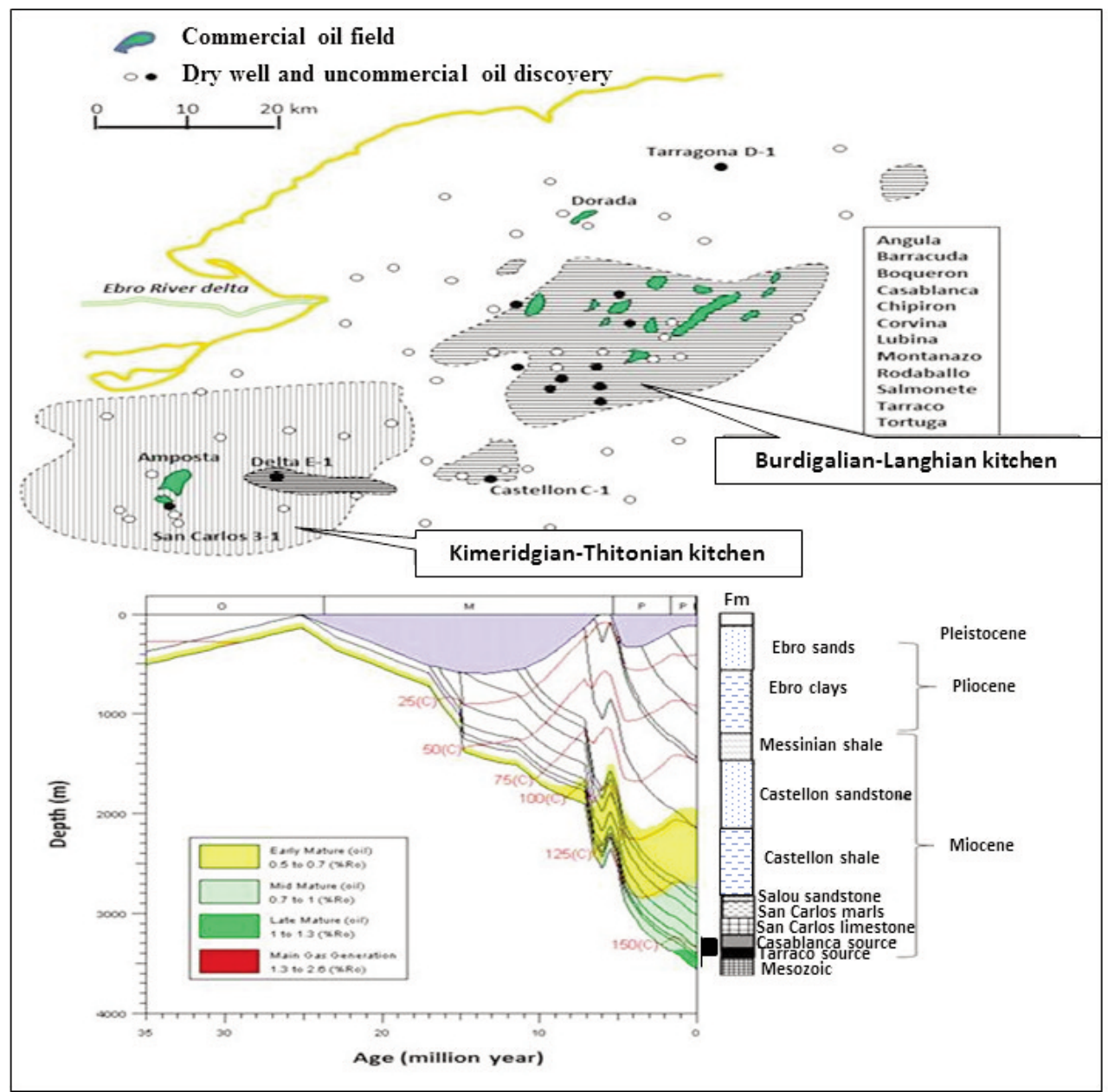

Figure 9. Valencia Trough: Kimmeridgian and Early Miocene source rock and Casablanca Fm. maturity model (modified from Varela et al., 2005).

Figura 9. Golfo de Valencia: áreas rayadas indicando las zonas donde las rocas madres del Jurásico y del Mioceno han expulsado hidrocarburos según el modelo de maduración de la Fm. Casablanca (modificado de Varela et al., 2005). 
The sedimentary wedge shows thicker and deeper facies to the south with a sedimentary architecture configured (Martínez del Olmo, 1996) in five palaeogeographic domains: North Margin, Inner Platform, Outer Platform-Slope, Slope-Basin Plane (Figs.10 and 11). 2) During the Miocene the alpine orogeny originated a strong thin-skinned deformation propagated from basin to margin and included the gravitational fall of chaotic masses known as the Olistostrome unit.

The alpine fold and trust belt extends over more than $42,000 \mathrm{Km}^{2}$ and only eight exploration wells were drilled in it before 1986 (Fig.11). In 2005 the Murcia B-1 appraisal well was drilled.

The exploratory knowledge can be summed up in four main points:

1) Due to the high topography and high seismic velocity in carbonate outcrops, the inner platform provided a poor seismic quality. There is also thermal immaturity and intense reservoir water washing.

2) In the seismic lines, the relative autochthonous

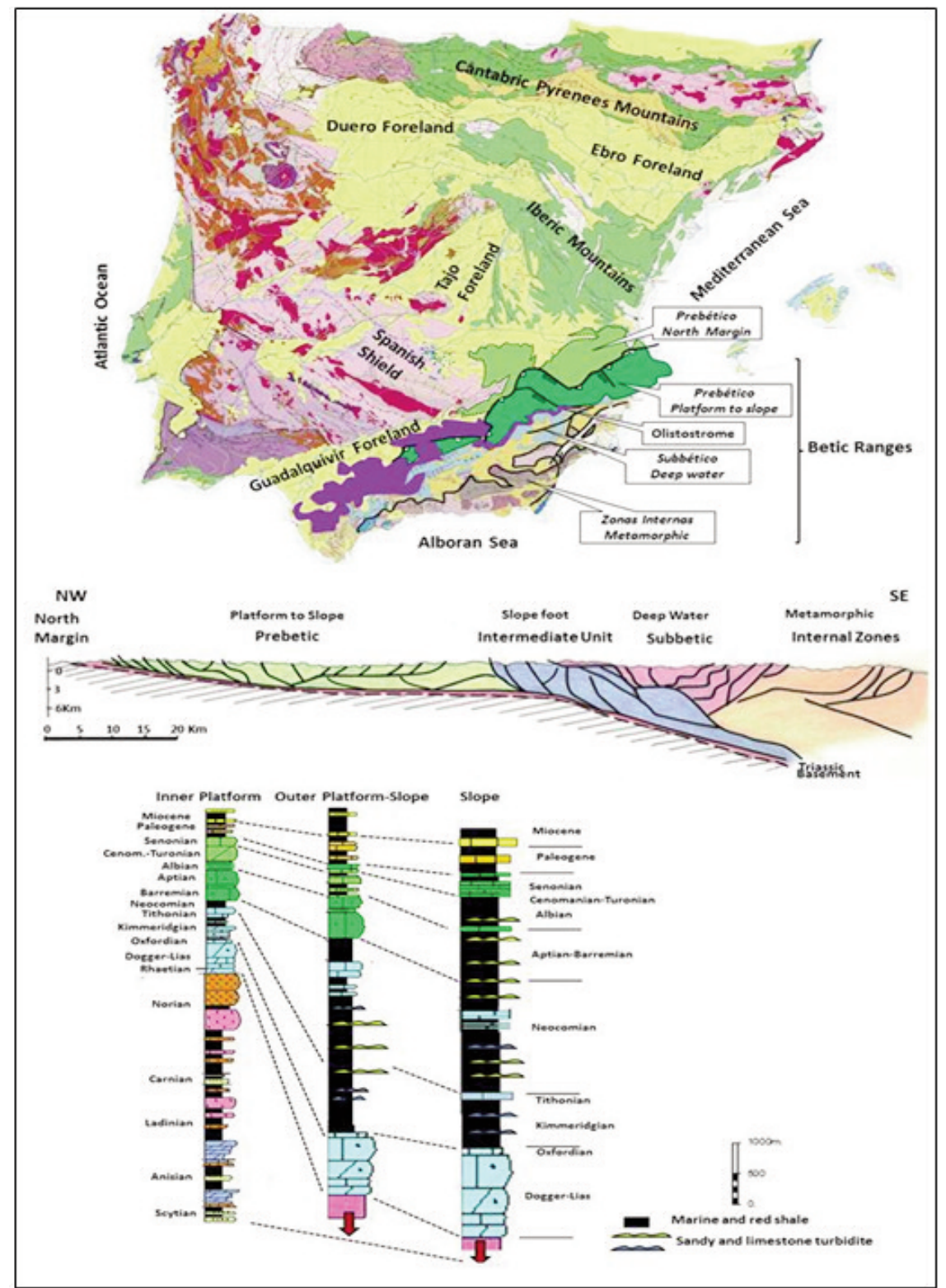

Figure 10. Prebetic outer platform-slope: paleogeographic zones and lithostratigraphic sketch (structural cross section from Banks and Walburton, 1991).

Figura 10. Plataforma externa-talud del Prebético: dominios paleogeográficos y columnas sedimentarias (esquema estructural según Banks y Walburton, 1991). 
is hidden under the Olistostrome when it is more than 400-600 metres thick. The Olistostrome reaches a thickness of 2,500 metres on the southern edge of the Guadalquivir basin.

3) The outer platform-slope shows a HauterivianBerriasian shale $4,000 \mathrm{~m}$ thick, which constitutes a poor, wet gas source rock.

4) Finally, on the slope foot-basin plane, the southernmost paleogeographic unit, has dead and washed oil in the limestone-dolomite Jurassic facies highs, probably due to early oil migration.
Despite the shows described above, the existence of a petroleum system was not confirmed until 1984 with the drilling of the Rio Segura G-1 well that showed strong gas kicks over $1,500 \mathrm{~m}$ thick intervals and two productive DSTs in the Barremian limestone $(2,000 \mathrm{~m}$ deep $)$ and the Valanginian turbidite thin sand $(4,000 \mathrm{~m}$ deep). The hydrocarbon type found is wet gas.

Despite the countless bibliography available on the Prebetic area, only a few papers describe seismic or well data (Martinez del Olmo, 1996; Martínez del

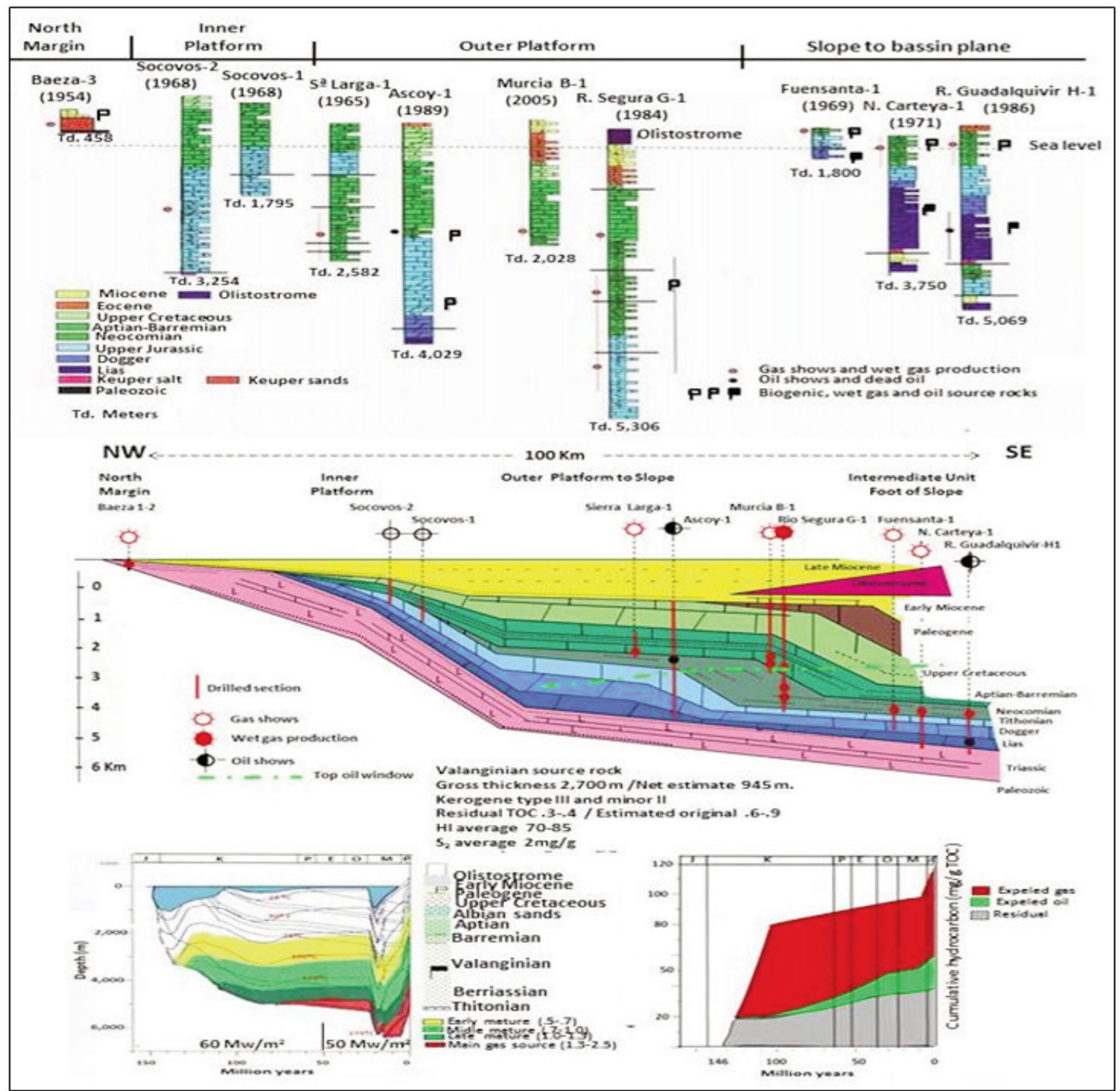

Figure 11. Prebetic data (margin-platform-outer platform-slope) and intermediate unit: well data, passive margin sketch and Valanginian source rock maturity model (from internal report OGC).

Figura 11. Prebético: sondeos, esquema sedimentario y modelo de maduración de la roca madre del Valanginiense (según informe interno de Oil and Gas Capital). 
Olmo et al., 1998; Barbero et al, 2001; Motis and Martínez del Olmo, 2012). The geochemical data of Sierra Larga-1, Ascoy-1, Rio Segura G-1 and Murcia B1 are only found in internal unpublished reports.

According to the data available, the Prebetic wet gas system is characterized by:

- A Valanginian deep water marine source rock (kerogen type III), poor (0.6 to $0.8 \%$ TOC) and thick (> $3,500 \mathrm{~m}$ ) which reached the expulsion of gas and condensate during the upper Cretaceous and is still active (Fig. 11).

- Thick Barremian-Aptian carbonate and sandy reservoirs, with low matrix porosity (3-6\%) and other sandy Hauterivian-Valanginian thin layers. The most recent studies show that open fractures have the maximum recoverable reserves.

- Intraformational seals provided by clays with different thickness or compact limestone intervals.

- Structural trap anticline types (hanging walls anticline or flower structures)

- A short and medium vertical migration, especially boosted by the intense transtensive and transpressive late faulting.

There is another possible but not confirmed dry gas system in the very deep Liassic and Kimmeridgian source rocks as has been recognized in some geochemical analysis over the uplifted outcrops of thrust sheets.

Due to the absence of a dense and quality seismic grid and the presence of only two deep wells (Rio Segura and Azcoy-1), the Valanginian source-rock extension is unknown, but it is supposed that this source (and also the possible Jurassic source), is related to the slope and base of the Cretaceous progradational system.

\section{Paleogene Foreland Basin (La Rioja)}

La Rioja is a narrow and tectonic depressed corridor that communicates the Duero and Ebro foreland basins (Figs. 2 and 4). Despite its small area $(3,300$ $\mathrm{Km}^{2}$ ), La Rioja has seven wells, so it can be considered fairly well explored. From unpublished well reports its sedimentary column can be explained as follows: 1) Paleozoic with a high-grade of metamorphism, 2) sandy-silty Albian with thin coal beds (100$150 \mathrm{~m}$ thick); 3) Cenomanian-Senonian marine compact limestone $(150-200 \mathrm{~m}) ; 4$ 4) thick Paleogene-Neogene continental, river facies in the central basin and conglomeratic alluvial fans in the north and south borders (3,500-5,000 m thick).

The exploration of the Rioja was performed in two phases, both having a good seismic quality available.
Seven wells were drilled during a first phase between 1975 and 1987. They picked up the first shows and non-commercial production of wet gas in the Upper Cretaceous limestone and Albian sands. A second phase, twenty years later, allowed the Viura commercial discovery (3-4 BCM) in a location very close to the old Rioja-5 well.

The current geological data in the Rioja (Jurado and Riba, 1996) and the wet gas system are described in some published papers (Carmona, 2016) and also in a number of unpublished internal reports. Data may be summarized as follows:

- The thin Albian shale and coal intervals are a very mature source rock (Fig.12) with vitrinite reflectance index (Ro.1.5).

-The sandy Albian levels (probably fluvial or desert facies) are reservoirs.

- The regional seal is to be found in the Maastrichtian and Paleogene red shale.

-Traps are mild anticlines bent to extensional or reverse fault systems that at the same time compartmentalize them.

- Migration must have been short-distance vertical probably during the Early Miocene, according to the vitrinite reflectance values (Ro) and the Rioja wells heat flow $\left(2.32\right.$ to $\left.2.48{ }^{\circ} \mathrm{C} / 100 \mathrm{~m}\right)$ similar to the surrounding Duero and Ebro foreland basins.

The absence of a regional 3D seismic data allows us to think that the Rioja basin may bring new discoveries of condensate gas in depths of about 4,0004,600 metres, especially to the east and south of the Viura gas field.

\section{Cantabrian Basin (both onshore and offshore)}

We denominate the Cantabrian basin as a both on and offshore geological area extending from the western Asturias Paleozoic massif to Navarre, where it links with the Pyrenean in the east. From north to south, it lies between two complex and regional Alpine thrust fronts: the north and south Pyrenean (Fig. 4). It has a surface of $26,000 \mathrm{~km}^{2}$ and its Mesozoic cover has been drilled by 146 onshore and 23 offshore exploratory wells. $95 \%$ of the wells were drilled before 1975, with poor quality seismic data, which is why here it is considered as an underexplored basin, especially onshore and in deep waters offshore.

The Cantabrian basin records a complex mosaic of facies (Fig. 13) developed during four main tecto-sedimentary stages: 1) Triassic-Jurassic rift; 2) Upper Jurassic-Cretaceous passive and active margin; 3) Paleogene, sin-orogenic phase; 4) Miocene, post-orogenic stage. 


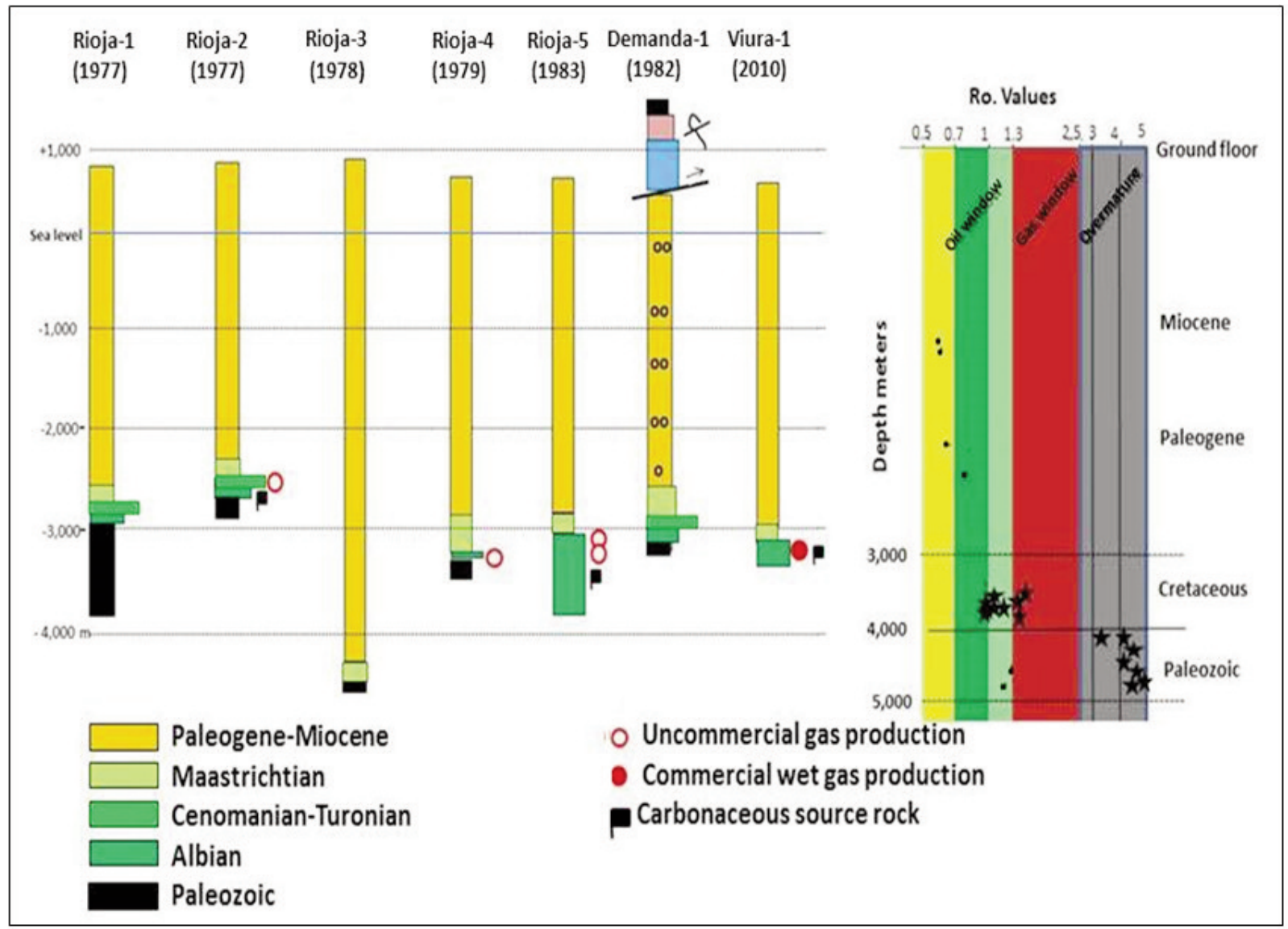

Figure 12. The Rioja alpine foreland basin: well data and vitrinite reflectance index values (Ro).

Figura 12. La cuenca antepaís de la Rioja: sondeos y datos de la reflectancia de la vitrinita.

As far as we know the basin contains two active petroleum systems that have produced four fields with commercial production (Castillo, Ayoluengo, Hontomin onshore and Mar Cantabrico M-1 in offshore shallow waters) and a number of non-commercial oil and gas discoveries (Fig 2) with the most significant being Mar Cantábrico C-2, C-3, C-4, Asturias D-1(offshore) and Cadialso-1, Tozo-1, 2, 5, Vitoria W-1, Navajo-1 and El Coto-1 (onshore).

As in the Prebetic, hundreds of published articles can be reviewed in order to have an overview of the basin stratigraphy and tectonics, but few of them describe the petroleum systems (Pujalte, 1977; Rodriguez-Paradinas and Ericson, 1980; Quesada et al., 1992, 1996, 2005; Borrego et al., 1996; Jenkyns, 1998; Martínez del Olmo and Mallo-García, 2002; Abeger et al., 2005; Varela et al., 2003).

From this data base, the petroleum systems of the Cantabrian basin can be summarized as:

-Two well-known source rocks: a) the PliesbachianEarly Domerian Marly Lias Formation, oil and gas prone, and b) the Albian-Cenomanian Valmaseda
Formation, wet gas prone. There is also a probable but not yet characterized dry gas prone Paleozoic source rock.

- Carbonated reservoirs are found in the Sinemurian, Aptian-Cenomanian-Turonian and Palaeocene. There are sandy reservoirs (deltaic and fluvial) in the Purbeck-Weald facies and turbidites in the Senonian of the Cantabrian Sea.

- Regional seals are marine with continental shales, siltstones and compact carbonates in the Jurassic and Cretaceous.

- Anticline type trap structures were built during the compressive Alpine stress.

- The vertical migration was short (Ayoluengo, Hontomin, Castillo) and long (Cantabrian Sea) with the expulsion mainly from the upper Cretaceous, before the generation of most of the structural traps.

Onshore, some factors have led to a low number of commercial fields due to operational and geological problems: the lack of modern seismic programmes, especially 3D, the DST in open- hole conditions, the hydrodynamic washing of reservoir facies 


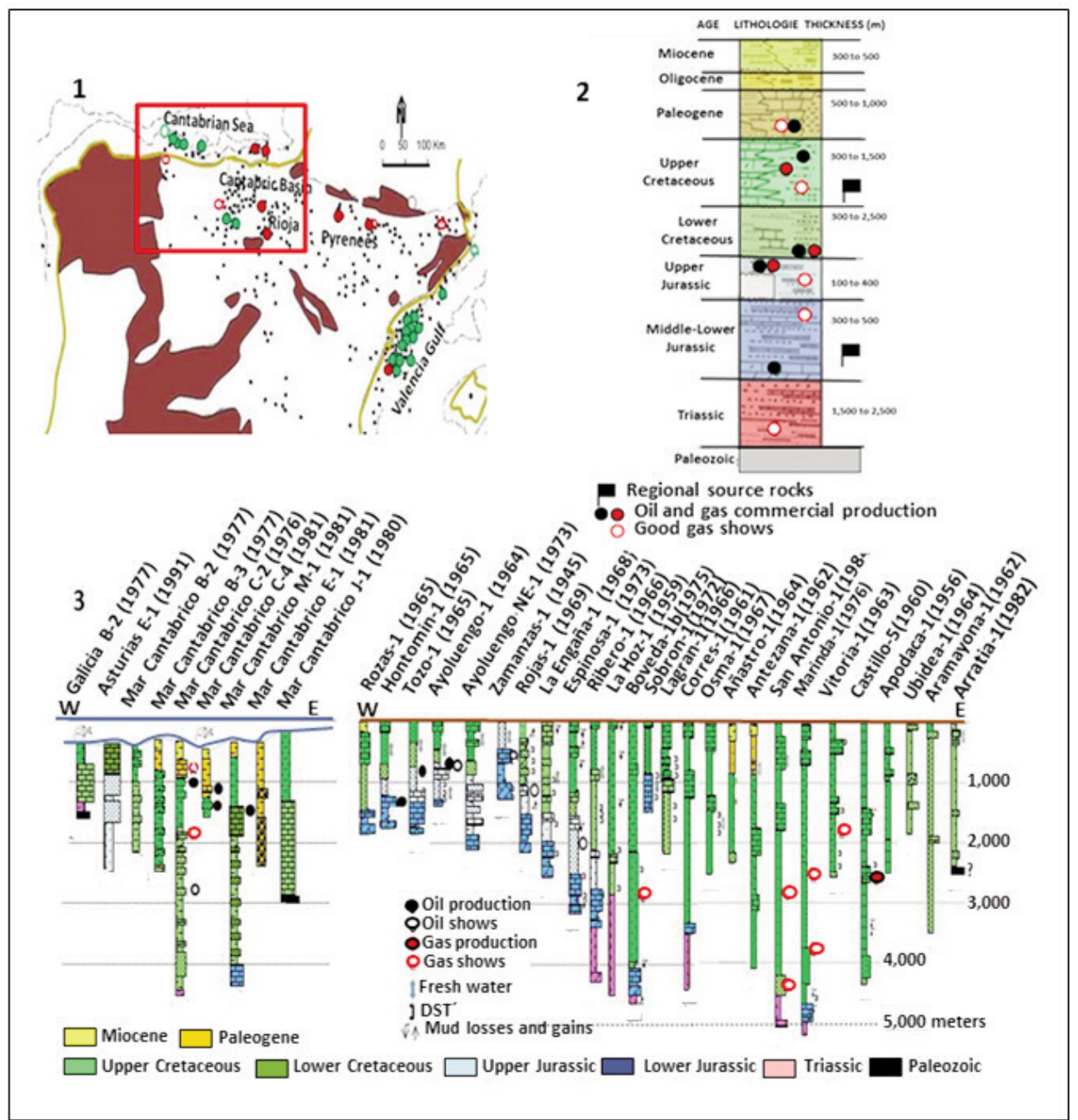

Figure 13. Cantabrian Basin: 1) location of wells. 2) Simplified geological map and hydrocarbon geology (from Abeger et al., 2005). 3) WE well data (from Repsol archives) and correlation.

Figura 13. Cuenca cantábrica: 1) Sondeos perforados. 2) Mapa geológico simplificado y columna litoestratigráfica con datos petrolíferos (según Abeger et al 2005). 3) Transversal O-E con datos de sondeo obtenidos de Repsol Exploración.

at shallow depths, and the main migration phase before the generation of structural traps.

Finally there is a possibility of using the hydraulic fracturing technique for the well characterized two source rocks (Sinemurian-Pliesbanchian, AlbianCenomanian, shale and clays) of the onshore Cantabrian basin, a technique and possibilities that we do not discuss in this paper due to lack of personal experience.

\section{Pyrenees Thrust Belt}

Here, only the southern Pyrenees (between the axial zone and the south thrust front over the Ebro foreland basin) are evaluated, since the northern part is not in
Spain (Fig.4). It covers an area of $13,000 \mathrm{~km}^{2}$ and has been drilled in 32 exploratory wells, which means a very low exploratory level ( 2.5 wells $\left.\times 1,000 \mathrm{~km}^{2}\right)$, especially considering that $90 \%$ of them were drilled before 1975.

Only two commercial discoveries have been found. They are the Aurin and Jaca, located very close to each other in the Serrablo field, dry gas type with $1,500 \times 10^{6} \mathrm{Nm}^{3}$ recovery reserves from a fractured limestone turbidite reservoir charged by Ypressian source rock. There are also non-commercial discoveries: oil from an Early Jurassic system of a source-rock reservoir in Benabarre 1 to 9 and Cajigar-1, wet gas from an Eocene petroleum system in Riudaura-1, and dry gas probably from a Lower Cretaceous sourcerock reservoir system in Centenera-1. 
As in the Betic ranges and the Cantabrian basin, several hundreds of papers can be consulted to obtain a good geological overview of the southern Pyrenees, but very few of them are about the petroleum systems (Cámara y Klimowitz, 1985, 1988; Melendez-Hevia and Alvaréz de Buergo, 1996; Martínez del Olmo and Mallo-García, 2002; Díaz Merino, 2001; Díaz-Merino et al., 2003, 2005; Álvarez de Buergo, 2005; Caja et al., 2006).

A summary of the petroleum systems (Fig. 14) is as follows:

- Four well-known source rocks are found:
Pliesbanchian (Benabarre and Cajigar), Lower Cretaceous (Centenera), Eocene (Riudaura) and Ypressian (Serrablo).

- Reservoirs are carbonates with low matrix porosity $(<3 \%)$ that occasionally have a moderate (Benabarre, Cajigar, Centenera) or intense fracturing that increases the production rate (Serrablo).

- Seals are compact carbonates or clays.

- Main traps are found in hanging wall anticlines.

- Migration was short and vertical and occurred several times, mostly before the main structural phase (Late Cretaceous- Eocene) but some during it.

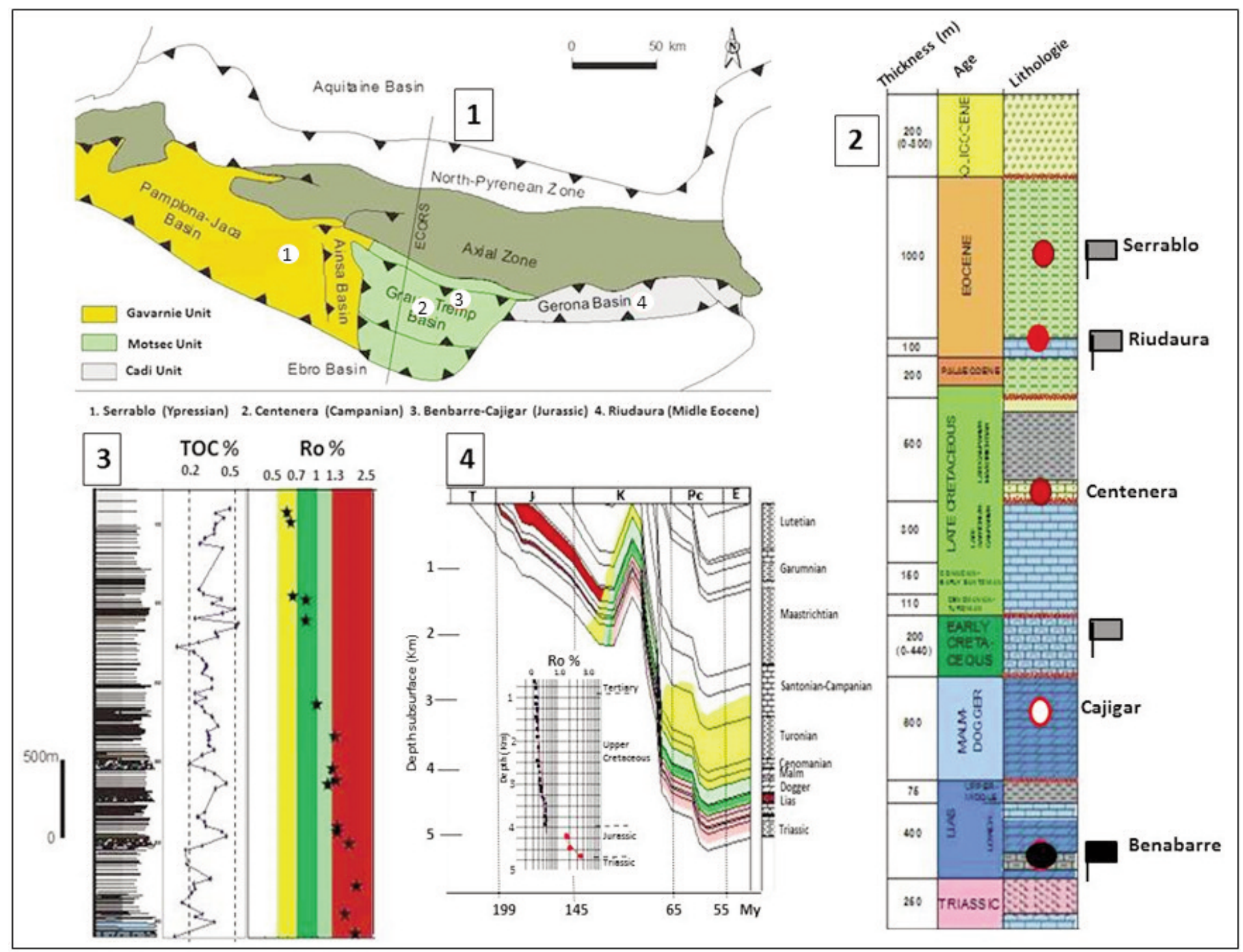

Figure 14. Pyrenees: 1) Tectonic units and key location of wells. 2) Regional stratigraphy with productive levels and source rocks. 3) Serrablo-Ypressian flysch source. 4) Burial graph of the Mesozoic-Eocene Graus-Tremp Basin (Montsec Unit) from Monesma-1 well data (Modified from Díaz Merino et al., 2005).

Figura 14. Pirineos: Unidades tectónicas y localización de sondeos productores. 2) Estratigrafía regional con rocas madre y niveles productivos. 3) TOC y Ro de la roca madre del campo Serrablo. 4) Modelo de maduración del sondeo Monesma-1(modificado de Díaz Merino et al., 2005. 
The Serrablo commercial gas field began being used for gas storage when it became practically depleted.

\section{West Aquitanie Foreland (Cantabrian Sea)}

The Aquitanie Basin is the north foreland of the Pyerenees, and it is mainly located in French territory. Only an offshore narrow segment of almost 3,200 $\mathrm{Km}^{2}$, located between the Cape Breton submarine canyon and the north-Pyrenean thrust in front of the Spanish Cantabrian coast, lies under Spanish waters (Fig 4).

Structurally it is quite complex, with an allochthonous unit with several north-verging thin-skinned thrusts over a basal detachment that leaves a tectonically simpler autochthonous underlying. As a result of this structural setting the seismic quality is very poor.

From seismic lines with very poor quality, the first

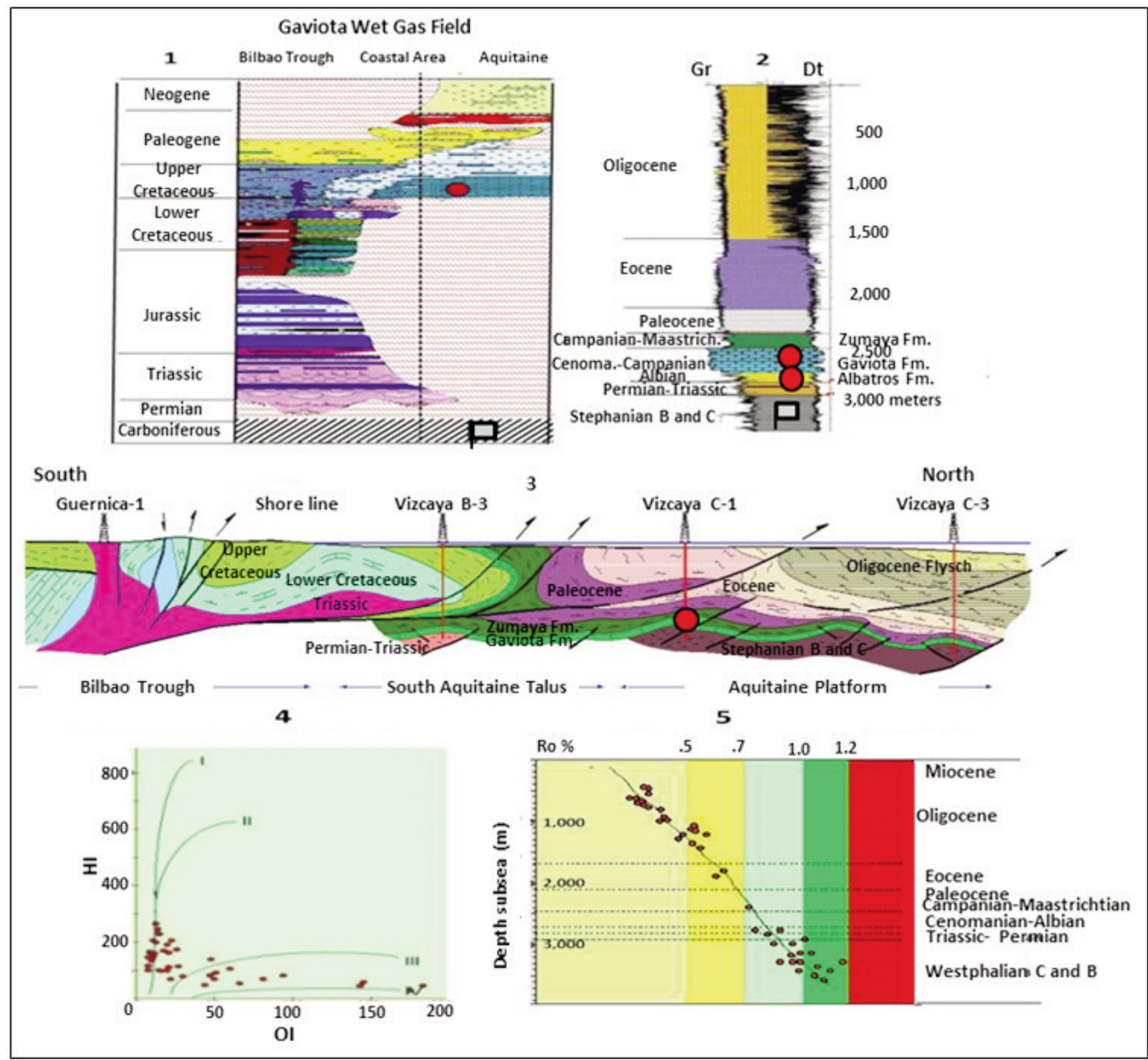

Figure 15. Aquitaine foreland: 1) Regional stratigraphy. 2) Vizcaya C-1 well log. 3) Structural cross section. 4) Kerogen type. 5) Maturity data. (from Cortés Hermoso de Mendoza et al., 2005).

Figura 15. Aquitania en el Golfo de Vizcaya: 1) Estratigrafía regional. 2) Rayos gamma y Sonic logs del sondeo Vizcaya C-1. 3) Corte geológico. 4) Tipo de kerógeno. 5) Datos de maduración (según Cortés Hermoso de Mendoza et al, 2005). 
oceanographic studies established that the northPyrenean front was found under the Cape Breton canyon. However, in 1980 hydrocarbon exploration and the drilling of Vizcaya C-1 showed that they were wrong. In fact, that exploratory well began crossing the tectonically complex north-Pyrenean front and penetrated a narrow autochthonous segment in continuity with the south Aquitaine platform Upper Cretaceous facies, establishing the base for the modern knowledge of that setting.

The area has been drilled by 10 exploratory wells $\left(0.3\right.$ well $\times 1,000 \mathrm{~km}^{2}$ ) and three commercial discoveries have been found (Gaviota, Albatros and west Albatros). They have accumulated 7,000 $\times 10^{6} \mathrm{Nm}^{3}$ of gas and $12 \times 10^{6} \mathrm{Bbl}$ of condensate. These figures are lower than the proven reserves because the Gaviota field was not fully depleted due to its use for gas storage. The gas reserves remaining were approximately $600 \times 10^{6} \mathrm{Nm}^{3}$.

The wet gas system has only been described by Cortés Hermoso de Mendoza et al. (2005) and can be summarized as:

- The source rock is found in the Stephanian B \& C dark shales (25\% TOC) and bituminous coal layers (50-60\% TOC). The vitrinite reflectance (Ro) ranges between 0.9 and 1.2 (Fig. 16) and the kerogen type is II-III.

- The main reservoir is the Gaviota Formation. It is a Cenomanian-Campanian inner to outer carbonate platform setting with $6-10 \%$ average porosity. A secondary reservoir is found in the Albatros formation (Albian muddy sands).

- The seal is the Zumaya Formation, a Late Campanian-Maastrichtian red shales unit, and also Late Albian intra-formational clays.

- The traps are in thrust-bend hanging wall anticlines.

- The migration was short distance vertical during the Late Eocene-Early Oligocene with some possible horizontal migration through the CarboniferousCretaceous unconformity.

The complex structure of the area, and the small surface covered 3D seismic data, lead us to consider that this $140 \mathrm{~km}$-long geological segment must contain numerous new prospects.

\section{Overlooked Areas}

Regarding the scope of conventional hydrocarbon potential, Spain is very lacking. This fact is mainly due to the low density of seismic surveys and exploratory wells found in many areas, the poor quality of the old seismic lines and other factors, such as the modern depreciation of hydrocarbon prices and the ecologist fight against fossil fuels. The main overlooked areas/ systems that will be developed here (Martínez del Olmo, 2004c) are:

1) The areas with oil and gas generation tested under the shallow waters of the Gulf of Valencia (Mediterranean Sea).

2) The deep waters of the Cantabrian, Mediterranean and Canary Islands, and the shallow waters of the Gulf of Cadiz.

3) Carboniferous basins.

4) Triassic red sandstone reservoirs.

5) Autochthonous and parautochtonous units under the Miocene Olistostrome of the Betic Cordillera.

6) Onshore Cantabrian Basin stratigraphic traps in the Upper Cretaceous sandy or limestone turbidites or in point bar channel fluvial facies (Purbeck and Weald / Upper Jurassic-Lower Cretaceous).

A new exploratory effort should be performed over all these settings. Improved results are not assured but strongly expected.

\section{Shallow and deep waters of the Gulf of Valencia (Mediterranean Sea)}

In the Gulf of Valencia, the Jurassic and Miocene the mature source-rock areas of the Valencia Gulf, only few have been covered by 3D seismic data. Therefore, a number of potentially commercial oil fields must remain undiscovered.

The deep waters are also practically overlooked despite having two recent commercial oil discovery examples, Lubina and Corvina (Fig. 16) close to Lower Miocene source rock, but the other possible sources (Lower-Upper Jurassic, Cretaceous, PaleogeneEocene) remain unknown. They should have a role in the thick sedimentary basins located SW and NE of the known Mediterranean productive area.

\section{Gulf of Cadiz shallow water, shallow and deep water Cantabrian sea, Balearic Sea and deep waters of the Canary Islands}

Most Spanish deep waters remain virtually unexplored and they contain all the ingredients that could leave to great discoveries, such as those found in the past three decades in the deep waters of many basins of the planet (Figs. 17 and 18):

a) The productive thin sands in the Gulf of Cadiz Messinian prograding complex (Fig. 8) where a dense $2 \mathrm{D}$ grid or $3 \mathrm{D}$ seismic cube would allow us to recog- 


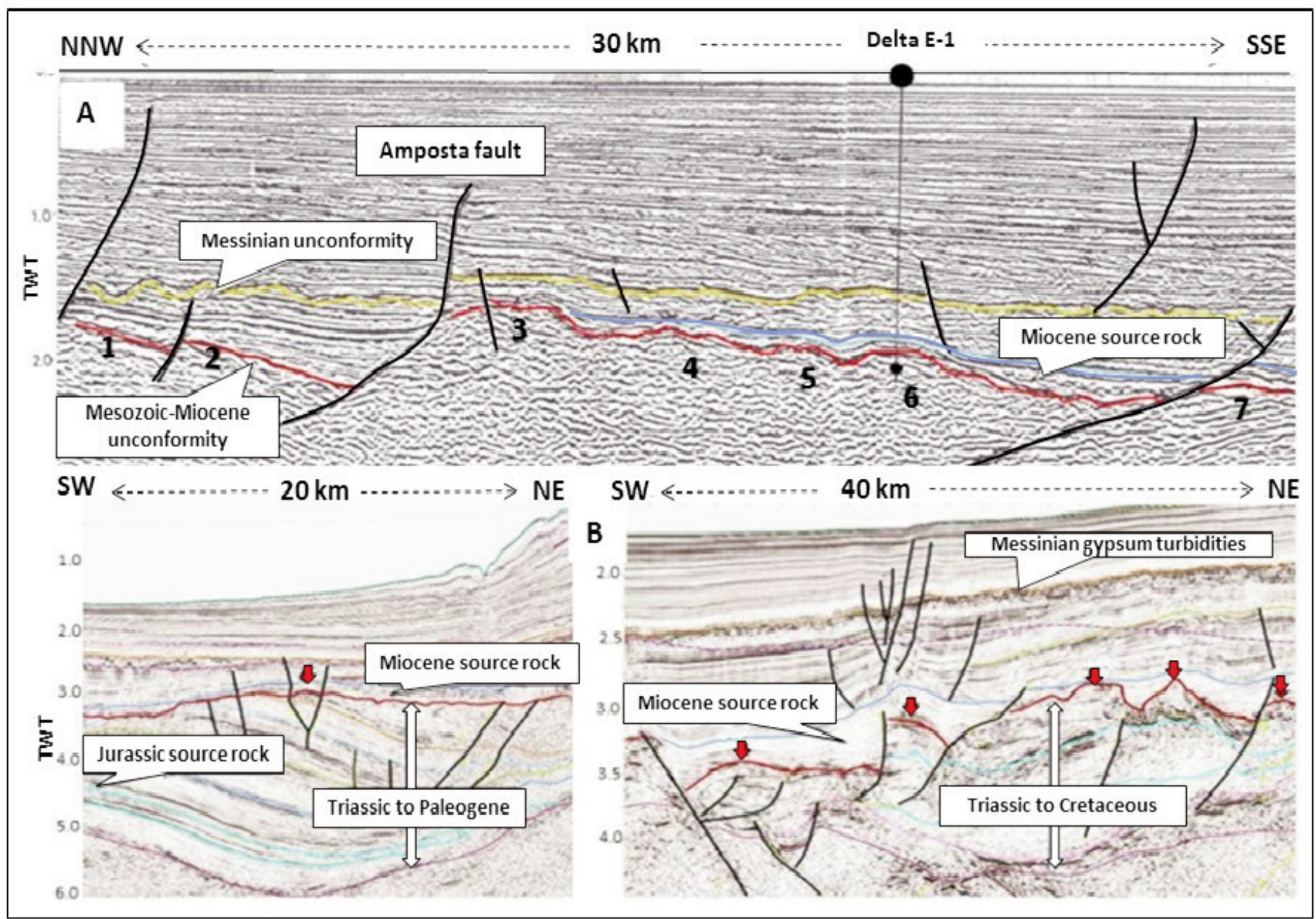

Figure 16. A) Valencia Gulf shallow waters: numbers show possible prospects established without 3D in the similar undeveloped oil field Delta E-1. B) Valencia Gulf deep waters (red arrows show possible prospects under the Mesozoic-Miocene unconformity, also established without 3D).

Figura 16. A) Golfo de Valencia: números mostrando posibles prospectos establecidos sin sísmica 3D en aguas someras semejantes al no desarrollado comercialmente yacimiento Delta E-1. B) Aguas profundas (flechas rojas señalando) las posibilidades existentes en la productiva discordancia Mesozoico-Mioceno en sísmica 2D.

nize some new gas fields with commercial possibilities, taking in to account the shallow water environment, the short distance to the shoreline and their daily production $(10,000-13,000$ Scf /day from the individual thin sand.

b) The deep waters of the Cantabrian Sea show possibilities in sandy turbidite deposits infill in Tertiary erosive canyon, Aptian carbonates build ups or finger reefs and Upper Cretaceous sandy turbidites.

c) Carbonates or sandy turbidites under the Messinian salt under deep waters surrounding the Balearic Islands (Martínez del Olmo, 2011; Martinez del Olmo and Martin, 2016a). The recent giant gas discoveries inside the Messinian carbonates in the deep water of the Nile River delta (Egypt) should constitute an analogue for this idea.

d) In the deep waters of the Canary Islands only one well has been drilled (Sandia-1). In it an oil show, a source rock and hundreds of metres of a Tertiary sandy turbidite reservoir were identified .Therefore, great possibilities are found in the many structural traps (four way closures), diapir flanks and stratigraphic traps that the thick sedimentary sections (7,000 metres) of theTertiary, Cretaceous and Jurassic, contain (Martínez del Olmo y Buitrago Borrás, 2002; Buitrago et al., 2003; Martinez del Olmo, 2004; Martínez del Olmo, 2005b). Taking into account the recent oil discoveries in West African deep waters, we can estimate that the unexplored areas in the Canary 


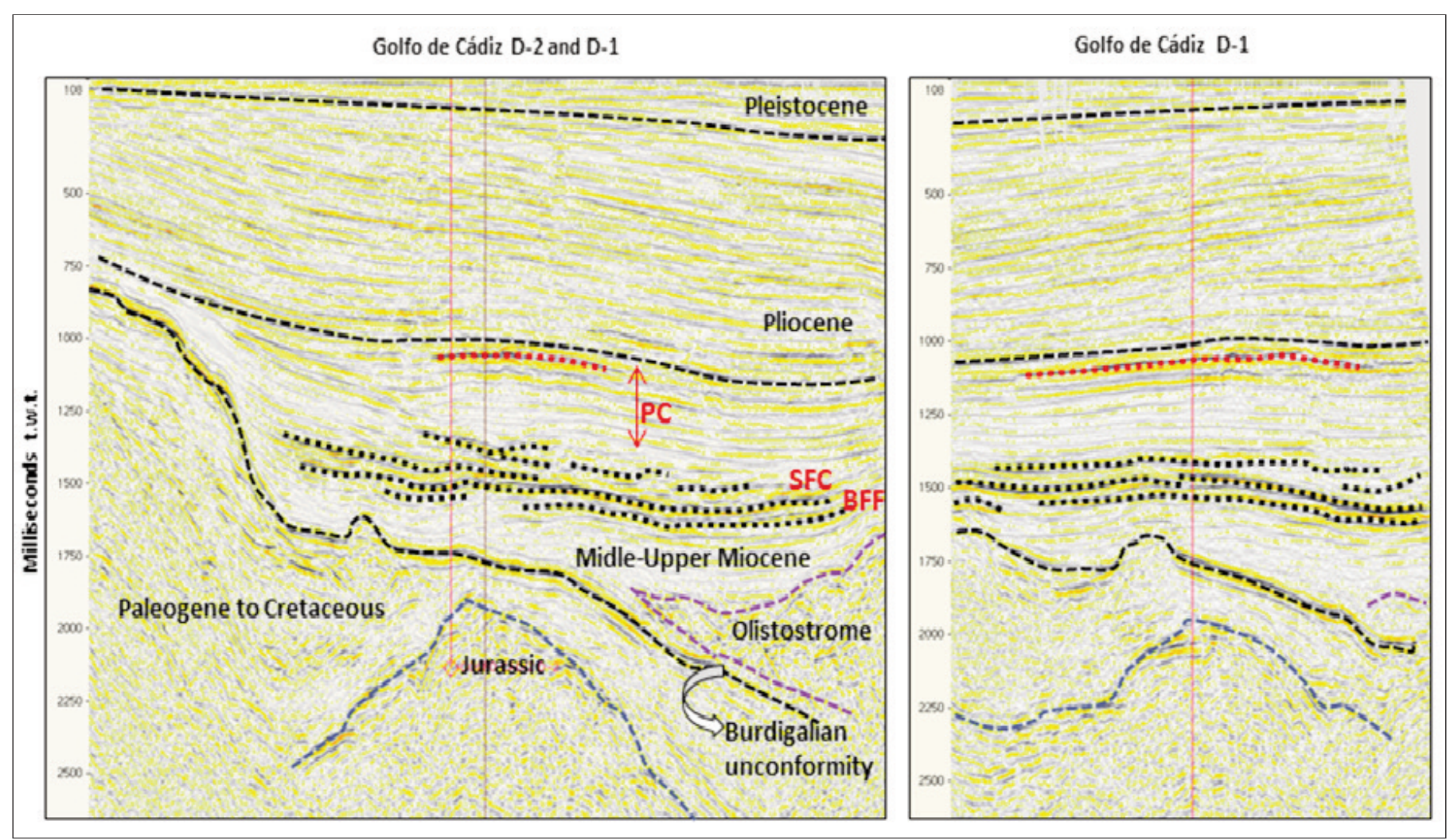

Figure 17. Gulf of Cadiz shallow waters: seismic lines 2D showing (red points) the thin sands of the prograding complex (PC) saturated gas that promoted the Shell mistake in D1that attributed the gas to the Jurassic dolomites when their drill perforated the top and the lost circulation promoted a significant gas flow. Mistake corrected by the Gulf of Cadiz D-2 well.

Figura 17. Aguas someras del Golfo de Cádiz: líneas sísmicas 2D mostrando (puntos rojos) las delgadas arenas del Complejo Progradante de la Formación Arenas del Guadiana, que saturadas en gas produjeron el error de Shell al perforar el sondeo Golfo de Cádiz D-1 que atribuyó el gas al Jurásico cuando su techo provocó pérdidas de circulación que ocasionaron un importante kick de gas. Error subsanado con la perforación del sondeo Golfo de Cádiz D-2.

Islands Cretaceous-Jurassic sedimentary sections would be the preferential target.

\section{Carboniferous basins and sub-basins (onshore Spain)}

Due to the onshore usually having low seismic grid, their bad quality and the absence of modern reprocessing, none of the Carboniferous basins and/or subbasins have been explored. Some of them do not crop out but are visible in the seismic lines (Fig. 20).

Recognized in many outcrops (Martínez Díaz, 1983) we know that they contain sandstone, conglomeratic and carbonate reservoirs facies that alternate with sapropels, carbonaceous shales and coal beds with different ranks of maturation: beginning of the oil window (Puertollano and Cordoba), advanced window of gas (Leon and Palencia) and immature (Teruel).

If we use the Gaviota and Albatros fields as ana- logues, the sub-basins of the Carboniferous not only contain an exploratory potential by themselves (reservoir and seals as seen in Fig. 20) but they are also usually truncated by an angular first order unconformity (under Triassic, Cretaceous or Paleogene) that could had been an efficient migration pathway.

\section{Triassic red sandstone reservoirs (onshore Spain)}

In the whole of Spain, both onshore and offshore, the Triassic sandy reservoirs under the evaporitic Keuper facies have only been reached in 52 exploratory wells and may be only 2-3 investigated structural closures, especially in the Ebro foreland basin. According to Orti (1974) two main reservoir levels must be considered: the Basal Red Sands and the fluvial Keuper Manuel Formation (K2).

Surprisingly the Triassic was a main target in only 


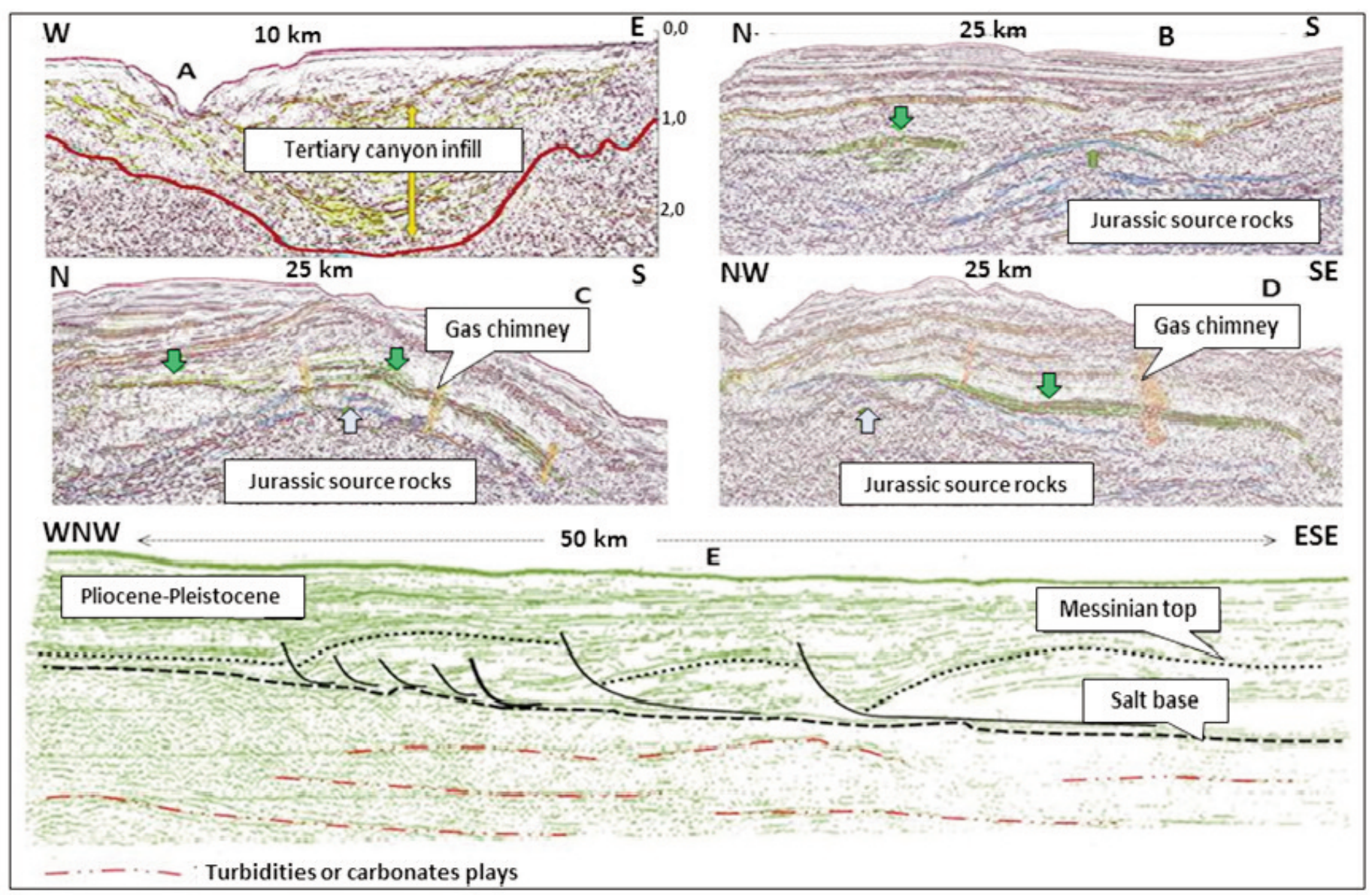

Figure 18. Cantabrian-Mediterranean seas: A) Tertiary canyon in shallow waters of the Cantabrian sea. B, C, D) Deep water seismic images (light green arrows: Upper Cretaceous sandy turbidities, dark green arrows: Barremian-Aptian carbonate finger reef). E) Possibilities below the Messinian salt in an unexplored large basin (deep waters of the Balearic Sea (from Martinez del Olmo, 2004c).

Figura 18. Mar Cantábrico: A) Cañón relleno de Terciario en aguas someras. B, C, D) Aguas profundas con prospectos en turbiditas del Cretácico Superior y complejos arrecifales del Urgoniano. E) Prospectos pre-Messiniense en el Mar Balear (desde Martínez del Olmo, 2004c).

10 to 15 of the 52 wells, when one of the most productive geologic horizons in Europe and Algeria is in fact the sandy Triassic. In fact, some thermogenic migrated gas, from a probable Carboniferous source rock, has been found in the Guadalquivir Basin at shallow depths (El Ciervo-1 and Baeza 1-2) and deep in the Cantabrian Basin (El Coto-1 and Navajo-1) where an older source rock (Devonian or Silurian) cannot be ruled out.

If we exclude the Ebro Valley, the Iberian mountains and the Inner Prebetic ranges, where the lack of gas shows indicate the probable absence of a Carboniferous source rock, there still remain a number of basins where the Triassic sandstones are unexplored. They are the Cantabrian Basin (both onshore and offshore), the Pyrenees, the Guadalquivir Basin, the deep waters in the Gulf of Cadiz and La Mancha foreland where the Puertollano source-rock mine (Stephanian-Permian) show the best source rock analyzed in Spain at the oil window maturity level.

The two Triassic sandstone reservoirs are deformed by an early rifting phase and a later compressive alpine deformation, and by the intense Keuper salt diapirism (Serrano and Martinez del Olmo, 1990, 2004). These three different styles of deformation allow structural traps under the Keuper evaporitic seal facies to be created.

\section{Para-authochtonous units under the Olistostromes of the Betic Ranges}

The Olistostromes of the Betic Ranges are a thick unit (up to $2,000 \mathrm{~m}$ ) of disorganized saline and clay, lithologies which perfectly seal several Prebetic 


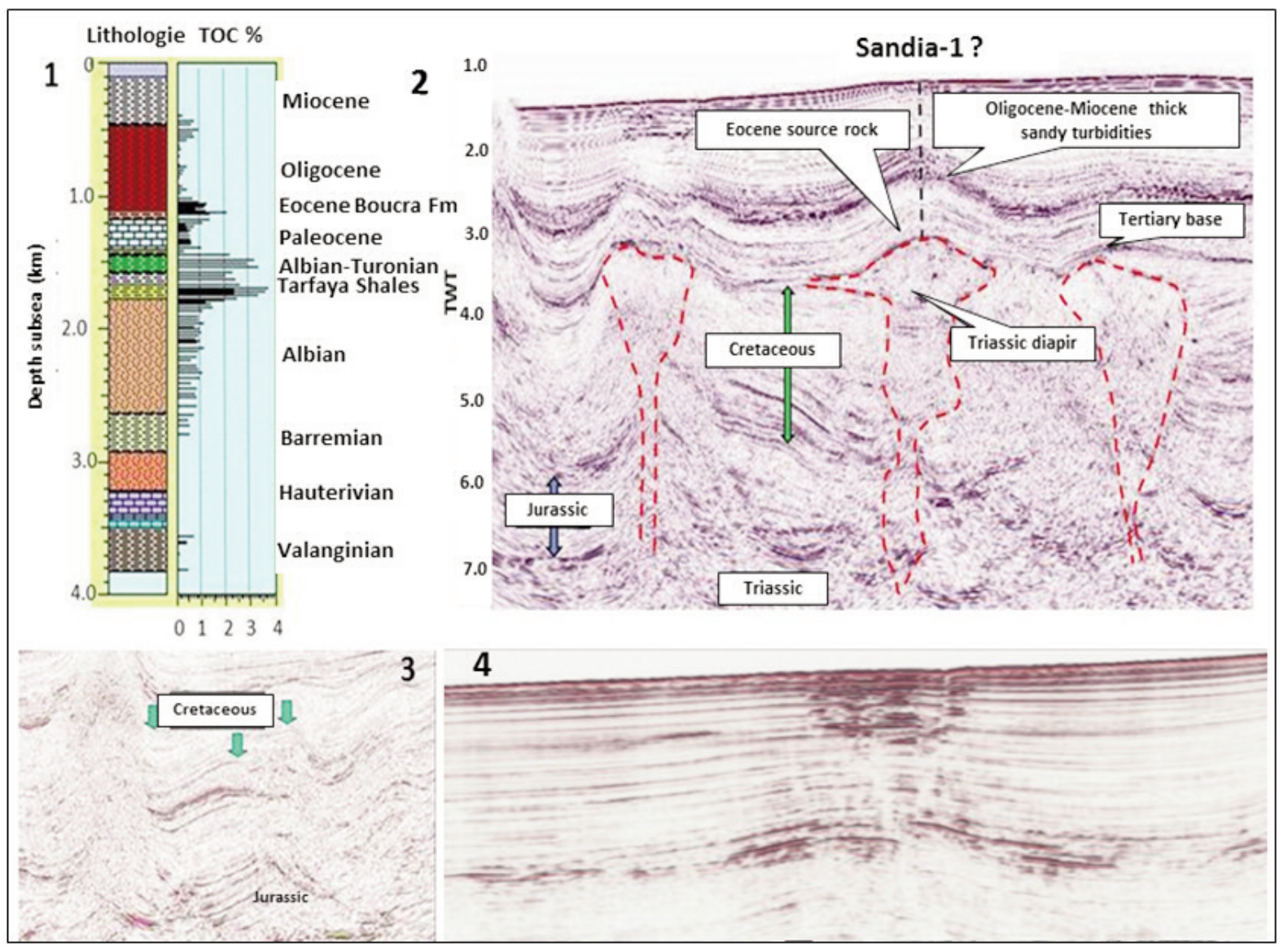

Figure 19. Deep waters of the Canary Islands: 1) Geochemical data of a nearby well (TOC total organic carbon). 2) Interpretation of a 2D seismic cross section. 3) Cretaceous-Jurassic prospects: diapiric flank and inter-diapiric anticlines. 4) Seismic lines with a direct hydrocarbon indicator /DHI. (modified from Martínez del Olmo, 2005).

Figura 19. Canarias aguas profundas: 1) Geoquímica de un sondeo próximo. 2) Interpretación de línea sísmica en 3D. 3) Prospecto en un Cretácico-Jurásico interdiapiros. 4) Indicadores (DHI) de generación de hidrocarburos (modificado de Martínez del Olmo, 2005).

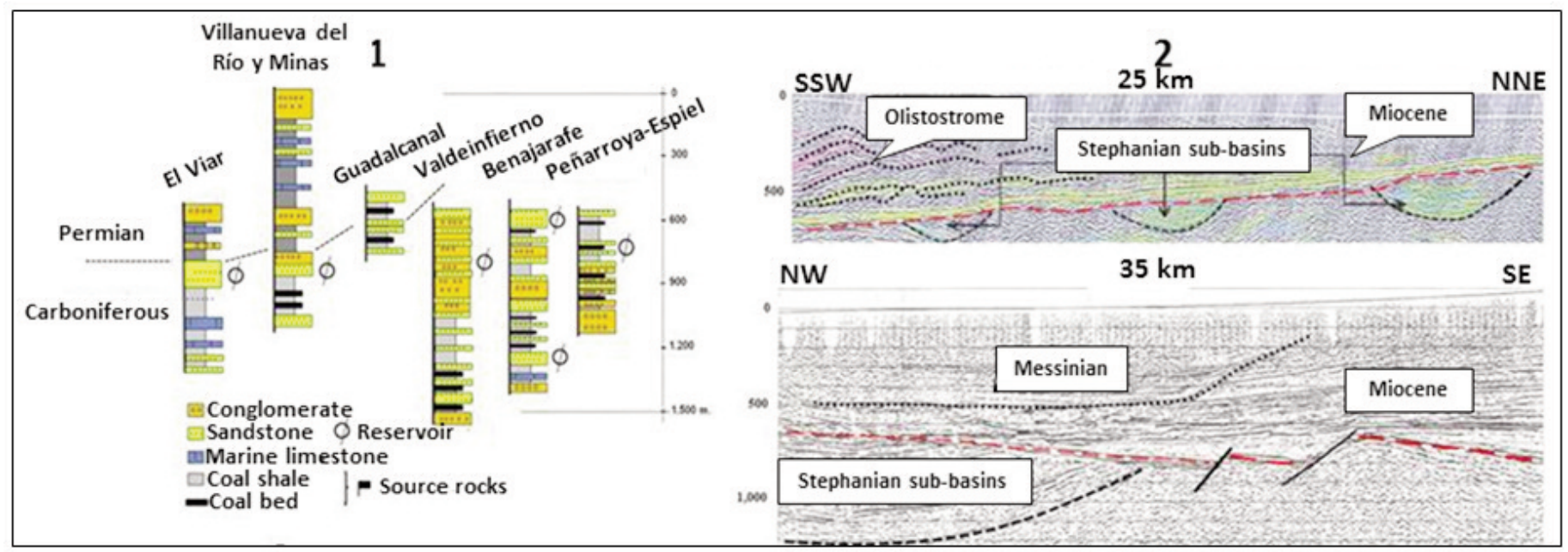

Figure 20. 1) Carboniferous source and reservoir possibilities from Cordoba outcrops data. 2) Seismic line showing Carboniferous buried basins in the Guadalquivir basin.

Figura 20. 1) Almacenes y roca madre en afloramientos del Carbonífero de la serranía de Córdoba. 2) Subcuencas del Carbonífero bajo el Mioceno del Guadalquivir. 


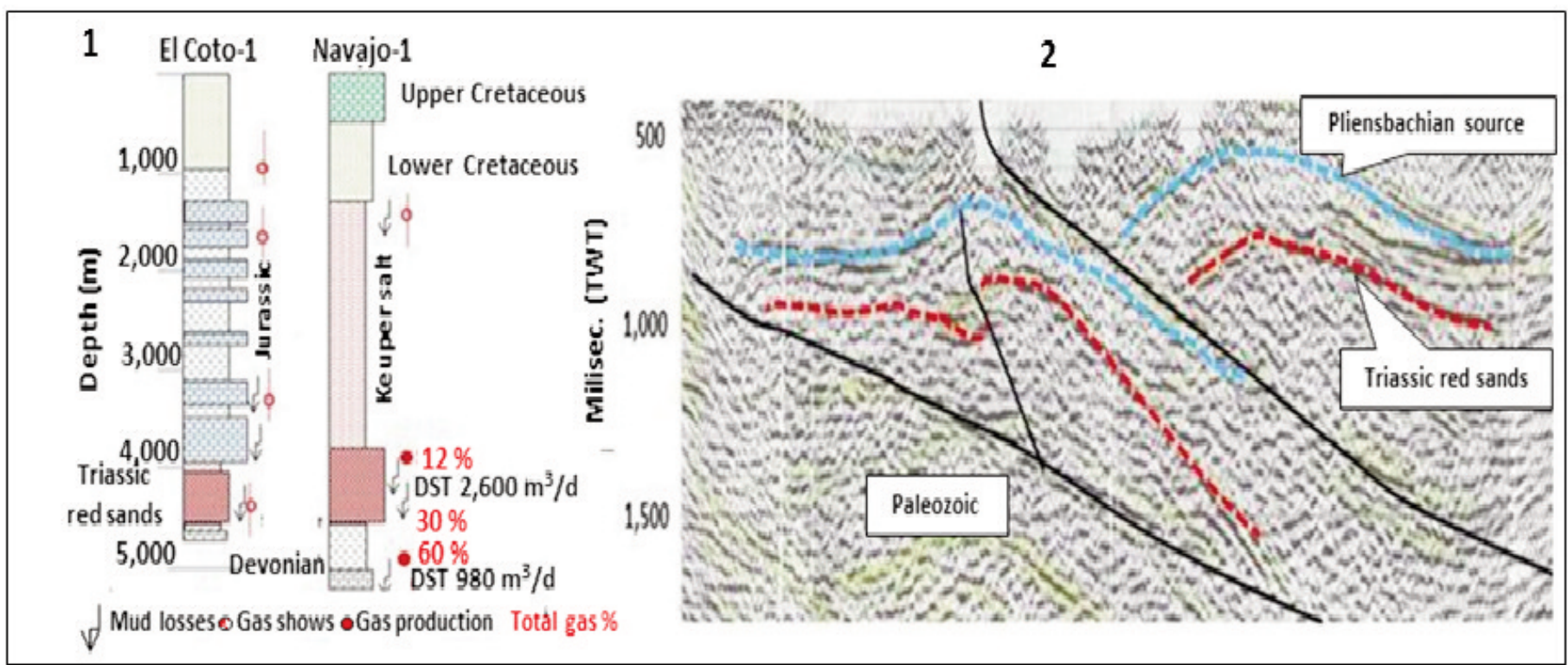

Figure 21. 1) Triassic red sandy facies in Navajo-1 and El Coto-1 well data. 2) Example of the unexplored possibilities in onshore Cantabrian basin (red, Triassic sandstone, blue the base of marine Jurassic source rock). Paleozoic is possibly Carboniferous.

Figura 21. Presalino de la cuenca Cantábrica: 1) Indicios y producciones de gas en elTriásico y Devónico de los sondeos Navajo-1 y El Coto1. 2) Ejemplo de posibilidades exploratorias no investigadas por sondeo (en rojo, las areniscas del Triásico, en azul la roca madre jurásica. El Paleozoico es un posible Carbonífero.

Mesozoic units with many reservoir possibilities in sandstone and limestone interbedded with intraformational thin shale seals. The Prebetic units under the Olistostromes show a blind thrust structure with several hanging wall anticlines (Martinez del Olmo et al., 1998; Motis and Martínez del Olmo, 2012). The structure was set up before and during the gravitational sliding of the Guadalquivir Betic Olistostromes.

In outcrop geochemical campaigns on the Prebetic Mesozoic not covered by the Olistostromes, two good gas prone source rocks have been found in the Valanginian and Kimmeridgian levels. One possible oil-gas prone source rock was also found in the Sinemurian black shale and limestone.

Due to the lack of control of the wells, the area may be defined as frontier, but with a non-negligible exploratory potential, especially for gas.

\section{Stratigraphic traps onshore Cantabrian Basin}

In the western part of the basin, the sedimentary sections of the Purbeck and Weald facies contain numerous sandstone channels, fluvial or deltaic (Pujalte, 1977) and buildups in the Aptian carbonates (García Mondejar et al., 2004). Those facies have produced oil and gas in structural traps (Ayoluengo and Mar Cantábrico M-1 oil fields) but have not been recognized by $3 \mathrm{D}$ seismic data in a large prospective onshore area. In the eastern onshore area, a similar problem can be found in the many turbidite channels, siliclastic or calcareous, present in the thick Upper Cretaceous slope and basin deep facies (see Fig.13).

The modern seismic processing techniques and a careful selection of areas to explore with 3D seismic coverage could lead to new fields. The expected size is difficult to predict, but stratigraphic traps could lead to bigger reserves than the structural traps.

\section{Discussion}

There is no doubt that the Spanish territory has not led the development of sedimentary basins with sufficient extension and thickness to generate oil provinces as in other many other places in the world. This is the main reason for the very low level of exploration that has caused an omgoing lack of knowledge of the exploratory possibilities from very early times (1980).

Thirty-seven years later, we must conclude that Spain cannot be considered as an "oil country", but, at the same time, it can be stated that in all its seven main basins (Guadalquivir-Cadiz, Valencia Gulf, Cantabric Basin, Pyrenes, Betic ranges, west Aquitaine and Rioja) there has been expulsion of oil and gas, hydrocarbon discoveries have been made, and some commercial production has happened.

In this study, we have tried to synthesize these petro- 


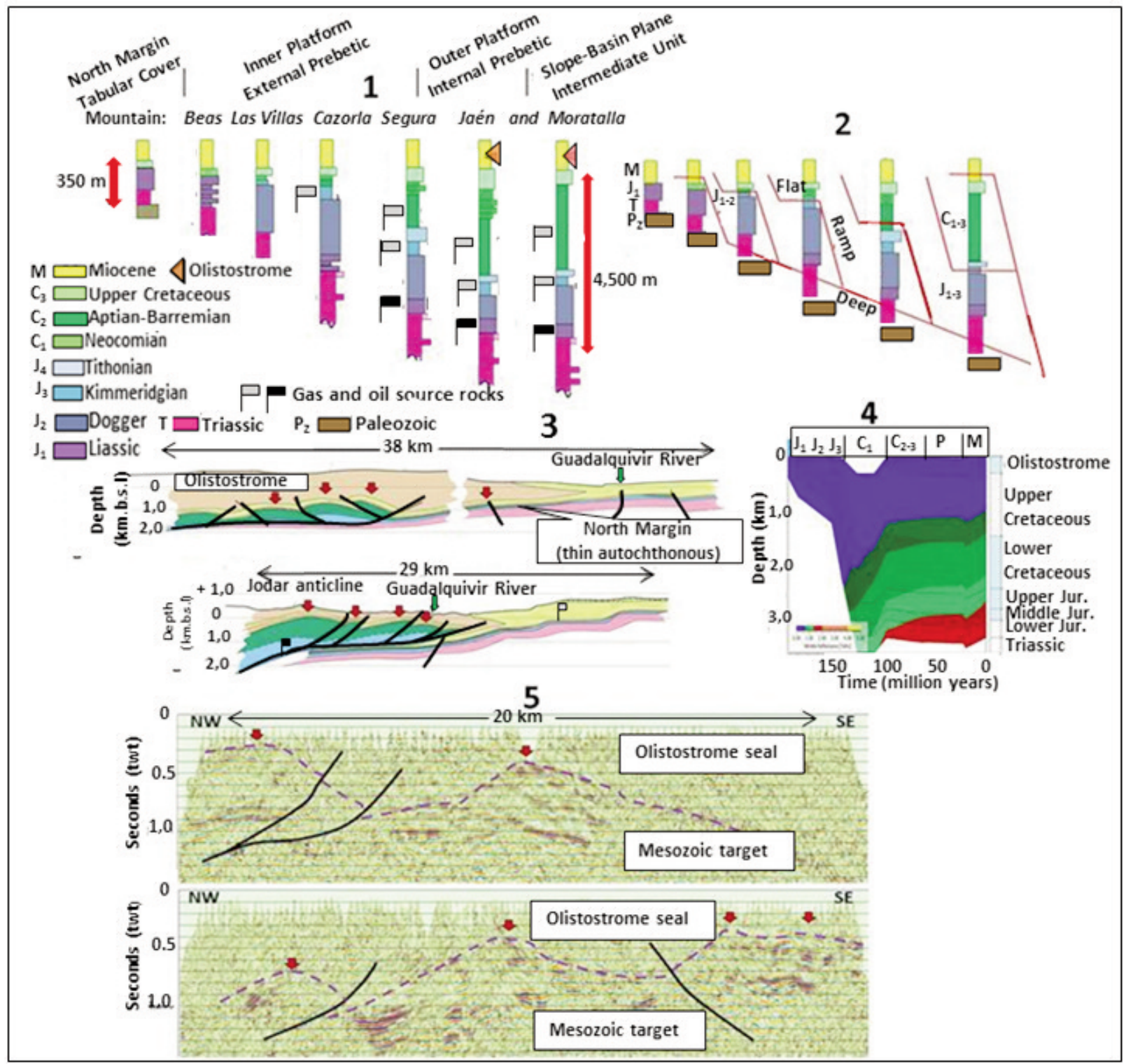

Figure 22. Betic Ranges under the Olistostromes: 1) Margin to basin sedimentary data from nearby outcrop data. 2) Structural model. 3) Cross sections showing the Mesozoic prospects (red arrows). 4) Mesozoic Units maturity model. 5) Old seismic lines reprocessed in year 2012 showing the blind thrust and prospect under the Olistostrome seal.

Figura 22. Cordillera Bética bajo los olistostromas: 1) Columnas sedimentarias desde afloramientos no cubiertos por el olistostroma. 2) Modelo estructural. 3) Flechas rojas indicando los posibles prospectos sobre cortes geológicos realizados con el apoyo de las líneas sísmicas. 4) Modelado de maduración desde los datos obtenidos en las campañas geoquímicas. 5) Líneas sísmicas reprocesadas en 2012 mostrando las posibilidades que ofrece el Mesozoico para-autóctono bajo el olistostroma.

leum systems (i.e. mature source rocks, reservoirs, seals, trap type and migration path way) which have led to the current level of oil reserves, low but real.

We have also outlined the outstanding issues, explaining their location and tecto-stratigraphic models. In fact, taking into account that Spain now imports $99.8 \%$ of the hydrocarbon it needs, we strongly believe that a new exploratory effort is essential.
Due the lack of accurate geochemical data, we have left open some questions related to some source rocks responsible for commercial and noncommercial discoveries. This is the case of the Centenera gas field, where it is supposed to be lower Cretaceous, but without any reliable data. A second case is the important gas show in the Triassic of the Navajo-1 and El Coto-1 wells, interpreted as coming from the Carboniferous by lateral migration or maybe 
from an older Paleozoic by vertical migration. There is also a possibility of a deep Jurassic source rock in the Prebetic outer platform. Finally, there are real possibilities for our unexplored Carboniferous basins.

\section{Conclusions}

The Spanish territory does not seem to contain sedimentary basins able to generate large oil provinces as in surrounding places found in Europe and North Africa. The main reason is the intense Alpine folding and the subsequent early rise of many areas on one side and the scarce sedimentary development and complexity of the foreland basins such as the Ebro, Duero, Guadalquivir-Cadiz and Tajo.

The exploration of these basins has been very poor, with few wells and the absence of modern seismic campaigns, and without the use of modern interpretation technologies that could evaluate their real exploratory possibilities.

According to what has been reviewed here, we can conclude that:

- Eleven oil-gas systems are found in Spain (Fig.6), fed from eight source rocks of the Carboniferous (Gaviota), Early Jurassic (Ayoluengo), Upper Jurassic (Amposta), Lower Cretaceous (Rio Segura), Upper Cretaceous (Castillo and Viura), Paleogene (Serrablo and Riudaura), Early Miocene (Casablanca) and Late Miocene (Cadiz Gulf and Guadalquivir).

- Other petroleum systems, which are less known, are possible. They define big unexplored areas: deep water Canary Islands, Cantabrian, Mediterranean, southern and eastern Balearic Islands, autochtonous and parautochtonous units under the Betic olistostromes, Carboniferous sub-basins and pre-salt Triassic sandstones.

- Spain is a country which has been scarcely and badly explored. In fact, its exploratory boom was thirty years ago.

The previous lines bring together enough reasons to seriously consider that Spain still has real possibilities, but it seems that major companies are not showing any interest in them. This fact is mainly due to logistic and operational difficulties promoted by public campaigns against fossil fuels, especially against the hydraulic fracturing technique.

\section{Acknowledgements}

I am grateful to the editor E. Pardo, and A. PérezLópez and the other two anonymous reviewers for their corrections to the original paper, and also my friends Alberto Garrido, Victor García-Dueñas and Luis Granados, all deceased, because long ago I was asked to carry out this work, and also to Kilian Motis who improved my English text.

\section{References}

Abeger, G., Serrano, A. and Quesada, S. 2005. Petroleum Geology of the Onshore Cantabrian Basin. En: 25 Aniversario Asociación de Geólogos y Geofísicos Españoles del Petróleo. (ed) W. Martínez del Olmo. Madrid, 155-162.

Álvarez de Buergo, E. y Meléndez-Hevia, F. 1994. Características generales de las subcuencas del margen penisular mediterráneo (Rift del Surco de Valencia). Acta Geológica Hispánica, 29, 1:67-79.

Álvarez de Buergo, E. 2005. La investigación de hidrocarburos en España.¿Una asignatura pendiente? En: 25 Aniversario Asociación de Geólogos y Geofísicos Españoles del Petróleo. (ed) W. Martínez del Olmo, Madrid, 309-341.

Banks, C. J. and Warburton, J. 1991. Mid-crustal detachement in the Betic system of southeast Spain Tectonophysics, 191, 275-289.

Barbero, L., López-Garrido, J. A., García-Hernández, M., Quesada, S. y Martínez del Olmo, W. (2001): Evolución termal Mesozoica de la Cuenca Prebética (Sierra del Segura) inferida mediante análisis de huellas de fisión en apatito: resultados preliminares. Geotemas, 3 (2), 155-160

Borrego, A. G., Hagemann, H. V., Blanco, C. G., Valenzuela, M. and Suárez de Centi, C. 1996. The Pliensbachian (Early Jurassic) "anoxic" event in Asturias, northern Spain: Santa Mera Member, Rodiles Formation. Organic Geochemistry, 25, 259-309.

Buitrago, J., Diaz-Merino, C. Nahim, M., Almorabet, A. and Martínez del Olmo. W. 2003. An Emergent Play in the Deep Water Basin Between Canary Island and Morocco. American Association of Petroleum Geologist. Barcelona. Abstract.

Cámara, P. y Klimowitz, J. (1985): Interpretación geodinámica de la vertiente centro-occidental surpirenaica. Estudios Geológicos, 41, 391-401.

Cámara, P., Rodriguez de Pedro, J. y Moreno, J. M. 1988. Serrablo gas field; an example of a trap in syntectonic brecciated reservoir, Pyrenees (Spain). Petroleum Geologist Bulletin. Abstract. V. 72, 993.

Caja, M. A., Permanyer, A., Marfil, R., Al-Aasm, I. S. and Martín-Crespo, T. 2006. Fluid flow record from fracturefill calcite in the Eocene limestones from the SouthPyrenean Basin (NE Spain) and its relationship to oil shows. Journal of Geochemical Exploration, 89, 27-32.

Carmona, L. 2016. La exploración y producción de hidrocarburos y el medio ambiente (El yacimiento de gas de Viura). En curso de exploración y producción de hidrocarburos. Universidad Politécnica de Jaén (Linares). Presentación oral $n^{\circ} 9.24$ p.

Cortés Hermoso de Mendoza, L., Riaza, C. and Martínez del 
W. Martínez del Olmo, 2019. The Spanish Petroleum Systems and the Overlooked Areas... Boletín Geológico y Minero, 130 (2): $289-315$

Olmo, W. 2005. Gulf of Biscay gas and Condensate fields. En: 25 Aniversario Asociación de Geólogos y Geofísicos Españoles del Petróleo. (ed) W. Martínez del Olmo, 147-155.

Demaison, G. and Bourgeois, T. 1985. Environment of deposition of Middle Miocene (Alcanar) carbonate source beds, Casablanca Field, Tarragona basin. Offhore Spain. In. Petroleum Geochemistry and Source potential of Carbonate Rocks. American Association of Petroleum Geologist. Studies in Geology, 18, 151-162.

De la Cruz, F. 1995. Geochemical Considerations in the Spanish Mediterranean: The Tarragona Trough. 17 th Organic Geochemistry. Donostia, 121-123.

Díaz Merino. C. 2001. Evaluación petrolífera de la Cuenca de Graus-Tremp. Master en Exploración. Imperial College, London. 43 p.

Díaz Merino. C, Villalobos, L., Vicente, J. C., Cámara, P. and Martínez del Olmo, W. 2003. Petroleum Geology of the Oil and Gas Comercial Discoveries in Spanish Basins: Souhtern Pyrenees. American Association of Petrolerum Geologist Bulletin Barcelona. V. 87, 13, 21-24.

Díaz Merino, C., J. C. Vicente Bravo, J. C., Villalobos, L., León, L., Cámara P. y Martínez del Olmo W. 2005. The Serrablo field, a comercial gas Discovery in the Jaca basin. En: Asociación de Geólogos y Geofísicos Españoles del Petróleo, XXV aniversario. (ed) $W$. Martínez del Olmo, Madrid, 131-146.

García Mojonero, C. and Martínez del Olmo, W. 2001. One sea level fall and four different gas plays: The Gulf of Cadiz, SW Spain. American Association of Petroleum Geologist, Denver, USA. A-68.

García Mojonero, C., Buitrago, J., Cakebread-Brown, J., Jiménez, A. y Martínez del Olmo, W. 2001. Un descenso eustático y tres tipos de turbiditas en una pequeña cuenca sedimentaria: factores de control (Golfo de Cádiz, SO de España). En Repsol-Ypf (Ed) I. Congreso Interno de Exploración \& Producción. Madrid.12 p.

García Mondejar, J., Fernández-Mendiola, P. A., Agirrezabala, L. M., Aranburu, A., López-Horgue, M. A., Iriarte, E. and Martínez de Riruerto, S. 2004. Extension del Albiense-Aptiense en la Cuenca Vasco-Cantábrica. En. Geología de España, J. A. Vera (ed.) Sociedad Geológica de España, 340-343.

Jenkyns, H. C. 1998. The Early Toarcian (Jurassic) anoxic event: Stratigraphic, sedimentary and geochemical evidence. American Journal of Science, 288, 101-105.

Jurado, M. J. and Riba, O. 1996. The Rioja Area (westermost Ebro basin): a ramp valley with neigbouring piggybacks. In. Tertiary basins of Spain the stratigraphyc record of crustal kinematics (P. Friend and C. Dabrio eds.) Cambridge Univesity Press, 173-179.

Ledesma, S. 2000. Astrobiocronología y estratigrafía de alta resolución del Neógeno de la Cuenca GuadalquivirGolfo de Cádiz. Tesis Universidad de Salamanca. 464 p.

Martínez del Olmo, W. 1996. Secuencias de depósito y estructuración diapírica en el Prebético Oriental e Ibérico de Valencia desde sondeos y líneas sísmicas. Tesis Doctoral. Universidad Complutense, Madrid, 206 p. 233 figs.

Martínez del Olmo, W. 2004a. La exploración en Canarias.
Curso en el Ilustre Colegio Oficial de Geólogos. Madrid. $141 \mathrm{p}$.

Martínez del Olmo, W. 2004b. La exploración de hidrocarburos en el Terciario de España. Boletín Geológico y Minero, 115 (3) 411-426.

Martínez del Olmo, W. 2004c. Potencial exploratorio de la Zona de Exclusividad Económica de España (ZEE) Cursos de verano del Escorial. Presentación oral. Madrid, $71 \mathrm{p}$.

Martínez del Olmo,W. 2005. Exploración y análisis de cuencas. Canarias aguas profundas. Curso Cátedra Repsol. Universidad Politécnica de Madrid, 41 p.

Martínez del Olmo, W. 2011. El Messiniense en el Golfo de Valencia y el Mar de Alborán: implicaciones paleogeográficas y paleoceanográficas. Revista de la Sociedad Geológica de España. 24 (3-4) 237-257.

Martínez del Olmo, W. and Esteban, M. 1983. Paleokarst development (West Mediterranean). In. (P. A. Scholle, D. G, Debout, C.M. More. eds.) Carbonate depositional environments. American Association of Petroleum Geologist. Memoir, 30, 93-95.

Martínez del Olmo, W. y García Mojonero, C. 2000. Cincuenta años de exploración en la Cuenca Guadalquivir-Golfo de Cádiz. Boletín de Información Petrolífera. Repsol-Ypf, 79-92.

Martínez del Olmo, W. y Buitrago Borrás, J. 2002. Sedimentación y volcanismo al este de las Islas de Fuerteventura y Lanzarote (Surco Fúster Casas) Geogaceta, 32, 51-54

Martínez del Olmo, W. and Mallo-García, J. 2002. An overwiev of the Hydrocarbon System in Spain. In: The Geology of Spain (W. Gibbon y T. Moreno, eds.) Geological Society. London. 494-499.

Martínez del Olmo, W. y Motis, K. 2012. Lo aprendido de la pasada exploración y un vistazo a su futuro. VIII Congreso Geológico de España. Oviedo, Geotemas, 13, 582-586.

Martínez del Olmo, W. and Martin, D. 2016a. The Messinian record of Spanish onshore and Offshore data (Atlantic Ocean and Western Mediterranean Sea). Petroleum Geoscience (In Thematic Set: The Messinian salinity crisis.) Work number 2015-085, 10 p.

Martínez del Olmo, W. y Martin, D. 2016b. El Neógeno de la cuenca Guadalquivir-Cádiz (Sur de España). Revista de la Sociedad Geológica de España, 29 (1) 35-58.

Martínez del Olmo, W., García Mallo, J., Leret Verdú, G., Serrano Oñate, A. y Suarez Alba, J. 1984. Modelo tectosedimentario del Bajo Guadalquivir. I. Congreso Español de Geología. Segovia, 1, 199-213.

Martínez del Olmo, W., Torrescusa, S., Riaza, C. y García, C. 1998. Stratigraphy and turbidite reservoir characterization of biogenic gas fields in the Guadalquivir-Gulf of Cadiz Miocene basins, SW Spain. American Association Petroleum Geologist. Rio de Janeiro, Brasil, 692.

Martínez del Olmo, W., García Mojonero, C. y Torrescusa, S. 2005. The Guadalquivir and Gulf of Cadiz gas basin. En: 25 Aniversario, Asociación de Geólogos y Geofísicos Españoles del Petróleo, (ed) W. Martínez del Olmo, Madrid, 105-121.

Martínez Díaz, C. 1983. Carbonífero y Pérmico de España. $X$ 
Internacional Congreso Carbonífero-Pérmico. Madrid, IGME, $502 \mathrm{p}$.

Meléndez-Hevia, F. and Álvarez de Buergo, E. 1996. Oil and gas resources of the Tertiary basins of Spain. In. Tertiary basins of Spain the stratigraphyc record of crustal kinematics ( $P$. Friend and C. Dabrio edis). Cambridge Univesity Press, 20-24.

Motis, K. y Martínez del Olmo, W. 2012. Los Cabalgamientos ciegos del Alto Guadalquivir (Provincia de Jaén). VIII Congreso Geológico de España. Geotemas 13, Oviedo, 154-158.

Orlopp, D. E. 1988. Casablanca Oil Field. Spain: A karsted carbonate trap at the shelf edge. Offshore Technology Conference (OTC) Paper 5734, 441-448.

Orti, F. 1974. El Keuper del Levante Español. Estudios Geológicos, 30, 7-46.

Pujalte, V. 1977. El complejo Púrbeck-Weald de Santander. Estratigrafía y sedimentación. Tesis Doctoral. Universidad del País Vasco. 204 p.

Quesada, S., Robles, S. y Comas-Rengifo, M. J. 1992. Caracterización, distribución y génesis de las facies generadoras del Lías medio del sector occidental de la cuenca Vasco-Cantábrica (Norte de España). III Congreso Español de Geología. Actas 2, 329-333.

Quesada, S., Robles, S. y Dorronsoro, C. 1996. Caracterización de la roca madre del Lías y su correlación con el petróleo del campo de Ayoluengo en base al análisis de cromatografía de gases e isótopos de carbono (Cuenca Vasco-Cantábrica, España). Geogaceta, 20, 176-179.

Quesada, S., Rosales, I. y S. Robles, S. 2005. Liassic organic facies in the Basque-Cantabrian basin (North Spain). En: Asociación de Geólogos y Geofísicos Españoles del Petróleo, 25 Aniversario. (ed) W. Martínez del Olmo, Madrid, 29-52.

Rodriguez-Paradinas, A. and Ericson, E. K. 1980. Castillo Gas Field, Spain. Abstract. American Association of Petroleum Geologist. Bulletin, 64, page 775.

Rossi, C., Goldstein, R. H., Marfil, R., Salas, R., Benito, M. I., Permanyer, A., De la Peña, J. A. y Caja, M. A. 2001. Diagenetic and oil migration history of the Kimmeridgian Ascla Formation, Maestrat Basin, Spain. Marine and Petroleum Geology. 18, 3, 287-306.
Riaza, C. and Martínez del Olmo, W. 1996. Depositional model of the Guadalquivir-Gulf of Cadiz Tertiary basin. In: Tertiary basins of Spain, the stratigraphic record of crustal kinematics. (P. Friend y C. Dabrio, eds.) Cambridge University, 330-338.

Serrano, A. y Martínez del Olmo, W. 1990. Tectónica salina en el Dominio Cántabro-Navarro: evolución, edad y origen de las estructuras salinas. En: F. Orti y J. M. Salvany (eds) Formaciones evaporíticas de las cuencas del Ebro y cadenas periféricas y de la zona de Levante. Enresa, Madrid, 39-53.

Serrano, A., y Martínez del Olmo, W. 2004. Estructuras diapíricas de la zona meridional de la Cuenca VascoCantábrica. En Geología de España. (ed. J. A. Vera, SGEIGME, Madrid, 334-338.

Seemann, U., Pumpin, V. F. and Casson, N. 1990. Amposta oil field. Structural Traps. I: Traps Associated with Tectonic Faultig. American Association of Petroleum Geologist. Special Publication, 1-20.

Suárez Alba, J., Martínez del Olmo, W., Serrano Oñate, A. y Leret Verdú, G. 1989. Estructura del sistema turbidítico de la Formación Arenas del Guadalquivir. En: Libro homenaje a R. Soler y José. Asociación de Geólogos y Geofísicos Españoles del Petróleo. Madrid, 123-132.

Stamplfi, G. M. and Höcker, C. F.W. 1989. Messinian paleoreliev from 3D seismic survey in the Tarraco Concession area (Spanish Mediterranean Sea). Geologie en Mijnbouw, 68, 201-210.

Varela, J., Gomez, C., Calvet, F., Esteban, M., Riaza, C., Cámara, P., Mallo-García and Martínez del Olmo, W. (2003): Petroleum Geology of the Oil and Gas Comercial Discoveries in Spanish Basins: Cantabrian Sea. American Association of Petroleum Geologist. Barcelona. Abstract \& Poster.

Varela, J., Vicente Bravo, J. C., Navarro, J., Esteban, M. y Martínez del Olmo, W. 2005. The oil fields in the Spanish Mediterranean Sea. En: Asociación de Geólogos y Geofísicos Españoles del Petróleo. 25 Aniversario. (ed) W. Martínez del Olmo, Madrid, 121-129.

Watson, H. J. 1982. Casablanca Field Offshore Spain, a Paleogeomorphic Trap. American Association of Petroleum Geologist. In. The deliberate Search for the Subtle Trap. Memoir, 32, 237-250.

Recibido: mayo 2018

Revisado: septiembre 2018

Aceptado: enero 2019

Publicado: junio 2019 
